\title{
Rapid changes in meridional advection of Southern Ocean intermediate waters to the tropical Pacific during the last $30 \mathrm{kyr}$
}

\author{
L.D. Pena ${ }^{\text {a,* }}$, S.L. Goldstein ${ }^{\text {a,b }}$, S.R. Hemming ${ }^{\text {a,b }}$, K.M. Jones ${ }^{\text {a,b }}$, E. Calvo ${ }^{\text {c }}$, C. Pelejero ${ }^{\text {c,d }}$, \\ I. Cacho ${ }^{\mathrm{e}}$ \\ ${ }^{a}$ Lamont-Doherty Earth Observatory of Columbia University, 61 Rt. 9W, Palisades, NY 10964, USA \\ ${ }^{\mathrm{b}}$ Department of Earth and Environmental Sciences, Columbia University, 61 Rt. 9W, Palisades, NY 10964, USA \\ ${ }^{\mathrm{c}}$ Institut de Ciències del Mar, CSIC, Pg. Marítim de la Barceloneta, 37-49, 08003 Barcelona, Spain \\ ' Institució Catalana de Recerca i Estudis Avançats, ICREA, 08010 Barcelona, Spain \\ e Geociències Marines, Dept. d'Estratigrafia, Paleontologia y Geociències Marines, Universitat de Barcelona. C/Martí i Franquès, s/n, 08028 Barcelona, Spain
}

\section{A R T I C L E I N F O}

\section{Article history:}

Received 18 October 2012

Received in revised form

19 February 2013

Accepted 25 February 2013

Editor: J. Lynch-Stieglitz

\section{Keywords:}

neodymium isotopes

planktonic foraminifera

intermediate water masses

Eastern Equatorial Pacific

Equatorial Undercurrent

Southern Ocean

\begin{abstract}
A B S T R A C T
The Southern Ocean is increasingly recognized as a key player in the general ocean thermohaline circulation and the global climate system during glacial-interglacial transitions. In particular, the advection of Southern Ocean intermediate waters (SOIW), like Antarctic Intermediate Water and SubAntarctic Mode Water, to the Eastern Equatorial Pacific (EEP), through a so-called "oceanic tunnelling" mechanism, is an important means for rapid transfer of climatic signals (such as heat, fresh water, salt, and chemical species) from high-to-low latitudes. However, information on how intermediate water advection rates changed in the past, and particularly during deglaciations, is fragmentary. We present new results for Nd isotopes $\left(\varepsilon_{\mathrm{Nd}}\right)$ in cleaned foraminifera shells (Neogloboquadrina dutertrei) for the last $30 \mathrm{kyr}$ at ODP Site 1240 in the EEP. N. dutertrei preferentially dwells in the lower thermocline, at the core of the Equatorial Undercurrent (EUC), and the $\varepsilon_{\mathrm{Nd}}$ variability over time provides a record of the changes in the $\varepsilon_{\mathrm{Nd}}$ of the EUC. Through mixing models we show that the EUC record is primarily controlled by changes in the volume transport of intermediate waters and not by Southern Ocean $\varepsilon_{\mathrm{Nd}}$ changes. Southern Ocean signals in the EUC are stronger during colder intervals (Younger Dryas, last glacial maximum and Heinrich stadials 1 and 2), in agreement with tropical Atlantic intermediate water records. In addition, covariations between $N$. dutertrei $\delta^{13} \mathrm{C}$, molecular biomarkers, and diatom productivity at Site 1240 confirm the intermediate water route as an important mechanism for the transfer of climate signals from high-to-low latitudes. Changes in the SOIW chemistry during the deglaciation are likely linked to the upwelling of 'old' deep waters in the Southern Ocean and subsequent export as intermediate waters, which are coeval with the atmospheric $\mathrm{CO}_{2}$ rise. Moreover, a comparison of multiple proxy records for the last $30 \mathrm{kyr}$ indicates a latitudinal shift and/or a change in the convection depth of intermediate waters in the Southern Ocean prior to the onset of the deglaciation.
\end{abstract}

(c) 2013 Elsevier B.V. All rights reserved.

\section{Introduction}

The important role of Southern Ocean intermediate waters in the global ocean thermohaline circulation has been widely recognized (e.g. Joint SOLAS-IMBER Ocean Carbon Research, 2007) and has increasingly attracted the attention of oceanographers, modelers, and paleoceanographers. It has been recently demonstrated that Southern Ocean intermediate water is the single most important pathway of anthropogenic $\mathrm{CO}_{2}$ from the atmosphere into the ocean (Gruber et al., 2009; Ito et al., 2010). Thus in the modern context of rapid increases in atmospheric

\footnotetext{
* Corresponding author. Tel.: +1 8453658733.

E-mail address: leopoldo@ldeo.columbia.edu (L.D. Pena).
}

greenhouse gas concentrations from anthropogenic activities, it is timely to focus on these intermediate water masses. Recent studies have suggested that Southern Ocean intermediate waters play important roles in rapid ocean and climate reorganizations (Carter et al., 2002; Pahnke and Zahn, 2005; Pahnke et al., 2008), and it has been recently documented that the formation rate of Sub-Antarctic Mode Water in the Southern Ocean is changing in response to increasing average global temperatures and shifts in the global hydrological cycle (Wong et al., 1999; Bindoff and McDougall, 2000; Biastoch et al., 2009). It is therefore important to constrain the role of these water masses in past climate changes.

Southern Ocean intermediate water (SOIW, a list of acronyms is given in Table 1) efficiently transports heat, salt, and other chemical species, including dissolved $\mathrm{CO}_{2}$, from high latitudes in 
Table 1

List of acronyms, abbreviations, and symbols in the text.

\begin{tabular}{|c|c|c|c|}
\hline AABW & Antarctic Bottom Water & LGM & Last Glacial Maximum \\
\hline AAIW & Antarctic Intermediate Water & NADW & North Atlantic Deep Water \\
\hline ACR & Antarctic Cold Reversal & [Nd] & Nd concentration \\
\hline B-A & Bølling-Allerød & NPIW & North Pacific Intermediate Water \\
\hline CDW & Circumpolar Deep Water & PB & Pre-Boreal \\
\hline EEP & Eastern Equatorial Pacific & PDW & Pacific Deep Water \\
\hline$\varepsilon_{\mathrm{Nd}}$ & Nd isotope ratio & PNG & Papua New Guinea \\
\hline EUC & Equatorial Undercurrent & REE & Rare Earth Element \\
\hline GNAIW & Glacial North Atlantic Intermediate Water & SAMW & Subantarctic Mode Water \\
\hline HS & Heinrich Stadial & SoIW & Southern Ocean Intermediate Waters \\
\hline ka & kiloyears BP (age) & WTA & Western Tropical Atlantic \\
\hline kyr & thousands of years (duration) & YD & Younger Dryas \\
\hline
\end{tabular}

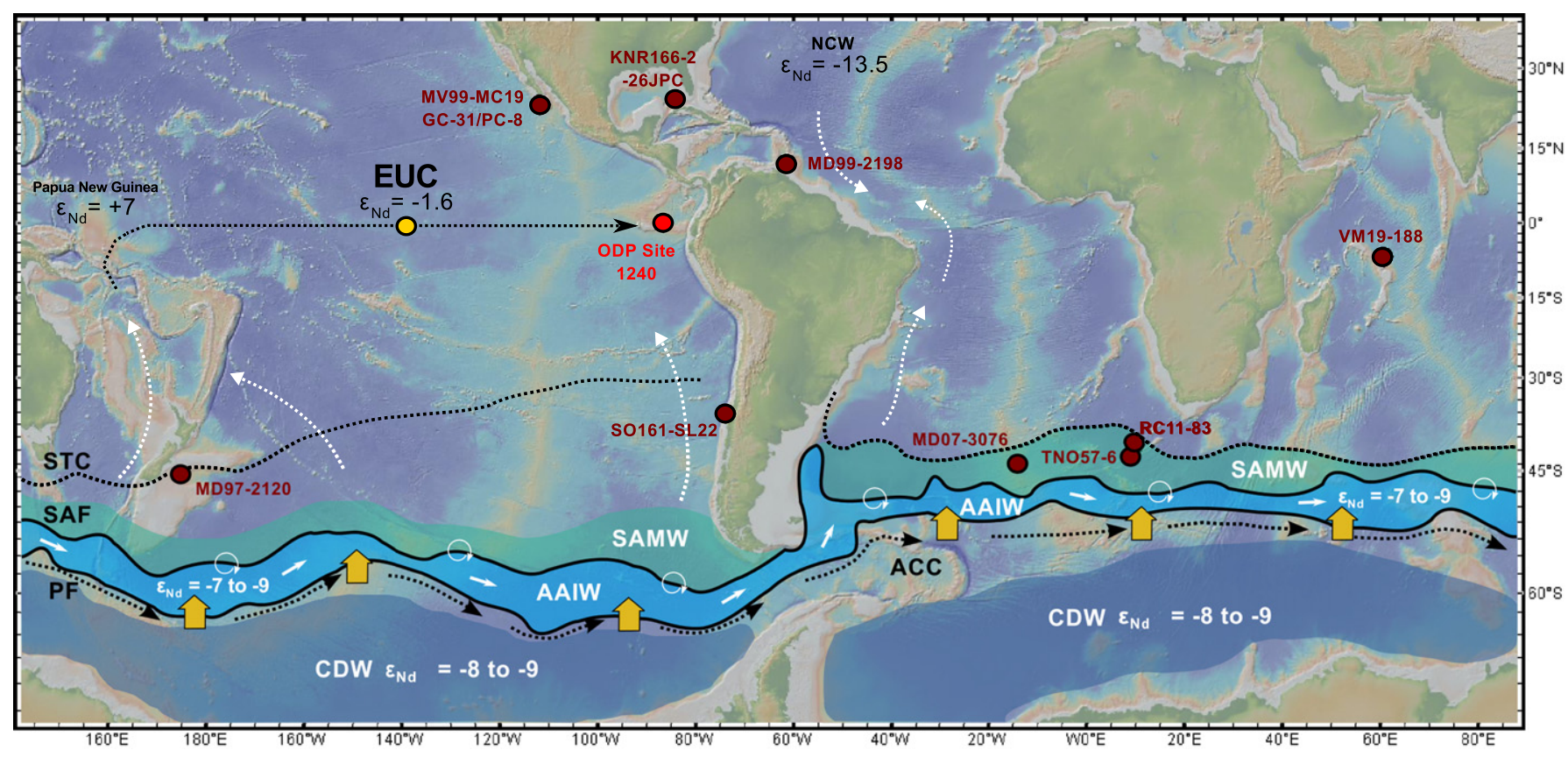

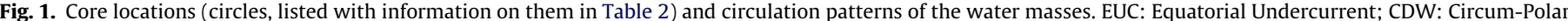

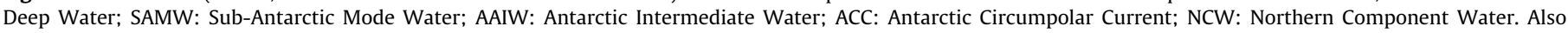

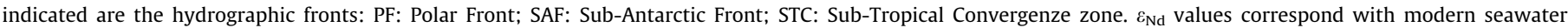
measurements (details in the text). Yellow circle corresponds to the $140^{\circ} \mathrm{W}$ hydrographic station for the EUC waters (Lacan and Jeandel, 2001 ).

the Southern Ocean towards tropical areas (Kessler, 2006). This "oceanic tunnelling" transports distinctive and traceable climate signals, which can be used to follow meridional tele-connection processes through time (Spero and Lea, 2002; Bostock et al., 2004, 2010; Pena et al., 2008a). Sub-Antarctic Mode Water (SAMW) forms north of the sub-Antarctic front (Fig. 1), and is the major precursor for Antarctic Intermediate Water (AAIW) (Toggweiler et al., 1991). SAMW ventilates the Pacific Ocean as AAIW by subduction and northward advection into the Pacific subtropical gyre from its main source in the southeast Pacific Ocean (Spero and Lea, 2002). In the southwest Pacific, older AAIW that formed in the southeast Pacific and passed through the Drake Passage also flows into the Pacific subtropical gyre, where it contributes to the Equatorial Undercurrent (EUC) in its source region in the western equatorial Pacific (Fig. 1; Lukas, 1986; Tsuchiya et al., 1989). Chlorinated fluorocarbon (CFC-11) data show that AAIW in the Pacific EUC includes a component that is only $\sim 25$ years old (Tsuchiya, 1991), suggesting that changes in water column chemistry at the Sub-Antarctic Front will be recorded in the chemistry of eastern equatorial Pacific (EEP) thermocline waters within a century or less. Therefore the tele-connection between the tropical Pacific thermocline and the Southern Ocean is rapid. In this study we present evidence of how the advection of SOIW into the EEP thermocline through the EUC changed rapidly along with major global climate changes over the last $30 \mathrm{kyr}$. This study is the first to apply $\mathrm{Nd}$ isotopes in thermocline dwelling foraminifera to reconstruct near surface ocean circulation in the EEP region.

\subsection{Nd isotopes in the global oceans}

In the modern oceans, seawater Nd isotope ratios generally covary with conservative water mass tracers such as salinity, and lateral and vertical $\varepsilon_{\mathrm{Nd}}$ gradients coincide with changes in water mass boundaries $\left(\varepsilon_{\mathrm{Nd}}\right.$ is the deviation in parts per $10^{4}$ of the measured ${ }^{143} \mathrm{Nd} /{ }^{144} \mathrm{Nd}$ ratio in a sample from the value of 0.512638 , the best estimate of average of chondrites, Jacobsen and Wasserburg, 1980). Because dissolved $\varepsilon_{\mathrm{Nd}}$ often approximates the expected value based on the mixture of water masses, and $\varepsilon_{\mathrm{Nd}}$ values are not significantly affected by biological productivity, air-sea gas exchange or temperature (e.g. Piepgras and Wasserburg, 1980; Jeandel, 1993; von Blanckenburg, 1999; Goldstein and Hemming, 2003; Jones et al., 
2008; Rempfer et al., 2011), Nd isotopes are often described as behaving "quasi-conservatively" in the oceans, at least away from ocean margins where "boundary exchange" may be significant (e.g. Lacan and Jeandel, 2005; Jones et al., 2008; Siddall et al., 2008). Globally, $\varepsilon_{\mathrm{Nd}}$ variability reflects the crustal age of the continental sources of Nd to the oceans (O'Nions et al., 1978, Piepgras et al., 1979, Goldstein and O'Nions, 1981), with the lowest values mainly in the North Atlantic (surrounded by old continental crust and with seawater $\varepsilon_{\mathrm{Nd}}=-13$ to -14 in North Atlantic Deep Water (NADW); Piepgras and Wasserburg, 1980; Piepgras and Wasserburg, 1987), the highest values in the North Pacific (impacted by circum-Pacific volcanism and with $\varepsilon_{\mathrm{Nd}}=0$ to -4 in Pacific Deep Water (PDW); Piepgras and Wasserburg, 1980; Piepgras and Jacobsen, 1988), and intermediate values in the Southern Ocean $\left(\varepsilon_{\mathrm{Nd}}=-7\right.$ to -9 , Piepgras and Wasserburg, 1982; Jeandel, 1993; Rickli et al., 2009, Stichel et al., 2012). The deep ocean residence time of $\mathrm{Nd}$ is estimated to be 500 1500 yr (Piepgras et al., 1979; Goldstein and O'Nions, 1981; Jeandel, 1993; Jeandel et al., 1995; Tachikawa et al., 1999, 2003; Bayon et al., 2004), long enough for the Nd isotopic signal to be advected by water masses far from the input locations, but short enough to prevent homogenization of its isotopic composition.

\subsection{Nd isotopes in the Equatorial Pacific}

Modern seawater Nd isotope ratios measurements in the EUC in the central Pacific $\left(\sim 140^{\circ} \mathrm{W}\right)$ have highlighted the existence of an Antarctic-derived water mass component in the tropical Pacific thermocline (Lacan and Jeandel, 2001), an observation that has been supported by other geochemical tracers such as benthic foraminifera $\delta^{13} \mathrm{C}$ (Bostock et al., 2010). This Antarctic component is incorporated into the EUC in its western Pacific source region and propagated eastward along the tropical thermocline (Fig. 1). $\varepsilon_{\mathrm{Nd}}$ in Circum-Antarctic water masses such as $\operatorname{SOIW}(\sim-7$ to -9$)$ are lower than Pacific water masses ( $\sim-4$ to 0$)$, therefore we expect that higher fluxes of SAMW-AAIW to the tropical thermocline are accompanied by decreases in $\varepsilon_{\mathrm{Nd}}$ of thermocline waters. While Nd may also be contributed to the EUC by sediments from Papua New Guinea (PNG), which have much higher $\varepsilon_{\mathrm{Nd}}(\sim+7$; Lacan and Jeandel, 2001) than surrounding waters, it is reasonable to assume that the $\varepsilon_{\mathrm{Nd}}$ in PNG sediments has not changed significantly over the past $\sim 30 \mathrm{kyr}$. Therefore, changes in $\varepsilon_{\mathrm{Nd}}$ of the EUC are likely linked to variations in the transport from SOIW, or to changes in the $\varepsilon_{\mathrm{Nd}}$ of the Southern Ocean end-member.

\subsection{Neodymium isotopes in foraminifera}

Foraminifera are the most commonly used substrate for paleoceanographic proxies. The first $\mathrm{Nd}$ isotope studies thirty years ago (Elderfield et al., 1981; Palmer, 1985; Palmer and Elderfield, 1985, 1986) concluded that the $\varepsilon_{\mathrm{Nd}}$ in uncleaned fossil foraminifera is dominated by contributions from $\mathrm{Nd}$ in $\mathrm{Fe}-\mathrm{Mn}$ coatings. Because these coatings also influence the foraminifera trace element inventories (e.g. Boyle, 1976, 1981, 1983; Boyle and Keigwin, 1982), cleaning protocols, including reductive and oxidative steps, were developed in order to remove them (Boyle, 1986). Fe-Mn oxides in sediments have much higher rare earth element (REE) concentrations than foraminifera, and it has only been over the last dozen years that $\varepsilon_{\mathrm{Nd}}$ measurements of cleaned planktonic foraminifera have been used to trace changes in shallow ocean waters (e.g. Vance and Burton, 1999; Burton and Vance, 2000; Pomiès et al., 2002; Vance et al., 2004; Stoll et al., 2007; Klevenz et al., 2008; Kocsis et al., 2008; Osborne et al., 2008). Although the mechanism that transports the Nd isotopic signal to the foraminiferal carbonates is debated (e.g. Pomiès et al., 2002; Vance et al., 2004), it is clear that the $\varepsilon_{\mathrm{Nd}}$ in cleaned planktonic foraminifera in these studies reflects the surface water in which the foraminifera calcified. Two recent studies have shown that in some cases the cleaning of foraminifera to remove Fe-Mn coatings can be challenging, with some reductively cleaned foraminifera shells still yielding deep ocean $\varepsilon_{\mathrm{Nd}}$ values (Elmore et al., 2011, Roberts et al., 2010, 2012). Therefore assessments of the cleaning procedures are necessary in order to validate that the measured $\varepsilon_{\mathrm{Nd}}$ reflects surface water values. For example, Roberts et al. (2010) used Fe-Mn encrusted foraminifera as a tool to reconstruct deep ocean circulation patterns at the Bermuda Rise in the North Atlantic. Their approach takes advantage of the high REE concentrations in the Fe-Mn coatings on the foraminifera, and measured $\varepsilon_{\mathrm{Nd}}$ values are in good agreement with measurements targeting only the authigenic Fe-Mn oxide phase from the same location (Gutjahr and Lippold, 2011), thus indicating that both approaches can yield deep ocean $\varepsilon_{\mathrm{Nd}}$ signals. However, these measurements on Fe-Mn encrusted foraminiferal have sometimes led to the misconception that planktonic foraminifera invariably record the deep ocean $\varepsilon_{\mathrm{Nd}}$ signature. We emphasize that in this study we have taken great pains to completely remove the $\mathrm{Nd}$ from $\mathrm{Fe}-\mathrm{Mn}$ coatings, and are reporting only carbonate-hosted $\varepsilon_{\mathrm{Nd}}$.

Nevertheless, there are observations that have not yet been fully explained. For example, the $\mathrm{Nd} / \mathrm{Ca}$ ratios in foraminifera (0.7-2.5 $\mu \mathrm{mol} \mathrm{Nd/mol} \mathrm{Ca)} \mathrm{reported} \mathrm{by} \mathrm{Vance} \mathrm{and} \mathrm{Burton} \mathrm{(1999)}$ and Burton and Vance (2000) are 500 times higher than seawater. While this result is consistent with inorganic partitioning experiments between calcite and seawater (e.g. Zhong and Mucci, 1995), the Nd concentrations [Nd] are high compared to some marine carbonates that show Nd/Ca ratios less than 20-30 times higher than seawater (e.g. Shaw and Wasserburg, 1985). Pomiès et al. (2002) reported $\mathrm{Nd} / \mathrm{Ca}$ ratios 16-52 times higher than local seawater in planktonic foraminifera collected with sediment traps and plankton tows. The cleaning techniques applied to sediment foraminifera generally result in low $\mathrm{Mn} / \mathrm{Ca}$ ratios that have no correlation with Nd/Ca ratios (Vance and Burton, 1999; Burton and Vance, 2000), and these authors concluded that the reductive cleaning step applied to sediment foraminifera successfully removes $\mathrm{Mn}$, but the particle reactive REEs may be re-adsorbed on the carbonate surfaces at the high $\mathrm{pH}$ necessary to prevent calcite dissolution. However, Haley and Klinkhammer (2002), using a flow-through cleaning system (thus minimizing readsorption), found that the reductive cleaning steps are effective at removing REE. They also found Nd/Ca $K_{d}$ values of $100-500$ (Haley and Klinkhammer, 2002), indicating that re-adsorption of REE on carbonates is very unlikely. In our foraminifera cleaning procedures, a final weak acid leaching step (Barker et al., 2003; Pena et al., 2005) removes REEs re-adsorbed onto the carbonate surfaces during the high $\mathrm{pH}$ reductive step.

\section{Materials and methods}

The samples in this study are from ODP Site $1240\left(0^{\circ} 01.31^{\prime} \mathrm{N}\right.$, $86^{\circ} 27.76^{\prime} \mathrm{W}$; $2921 \mathrm{~m}$, Table 2 ), spanning the last $30 \mathrm{kyr}$. The age model over this time interval is constrained using $13{ }^{14} \mathrm{C}$ ages (Pena et al., 2008a). In order to obtain measurable amounts of $\mathrm{Nd}$ for isotope analyses we picked 600 individuals ( $\sim 25 \mathrm{mg}$ ) per sample of $N$. dutertrei. Preliminary studies based on sediment traps and coretop $\delta^{18} \mathrm{O}$ measurements determined that $N$. dutertrei dwells preferentially between 150 and $170 \mathrm{~m}$ depth, at the core of the EUC (Fairbanks et al., 1982; Pena et al., 2008a). Detailed information on the cleaning protocols (Pena et al., 2005, 2008b) employed for sample preparation, the analytical techniques used in $\varepsilon_{\mathrm{Nd}}$ and REE measurements, and the data, are in the Supplementary Materials. 
Table 2

Locations, depths and proxy records presented in this study.

\begin{tabular}{|c|c|c|c|c|}
\hline Core site & Coordinates & $\begin{array}{l}\text { Depth } \\
\text { (m) }\end{array}$ & Proxy record (water mass) & References \\
\hline \multicolumn{5}{|l|}{ Pacific Ocean } \\
\hline ODP Site 1240 & $0.02^{\circ} \mathrm{N}, 86.47^{\circ} \mathrm{W}$ & 2921 & $\begin{array}{l}N \text {. dutertrei } \varepsilon_{\text {nd, }} \text { REE, } \delta^{13} \mathrm{C} \text { and sed. } \\
\text { biomarkers (EUC) }\end{array}$ & $\begin{array}{l}\text { This study, Pena et al. } \\
\text { (2008a) and Calvo et al. (2011) }\end{array}$ \\
\hline MV99-MC19/GC31 & $23.5^{\circ} \mathrm{N}, 111.6^{\circ} \mathrm{W}$ & 705 & ${ }^{14} \mathrm{C}$ ventilation age (AAIW) & Marchitto et al. (2007) \\
\hline SO161-SL22 & $36.22^{\circ} \mathrm{S}, 73.67^{\circ} \mathrm{W}$ & 1000 & ${ }^{14} \mathrm{C}$ ventilation age (AAIW) & De Pol-Holz et al. (2010) \\
\hline MD97-2120 & $45.53^{\circ} \mathrm{S}, 174.93^{\circ} \mathrm{E}$ & 1210 & $\delta^{13} \mathrm{C}$ benthic (AAIW) & Pahnke et al. (2008) \\
\hline \multicolumn{5}{|l|}{ Atlantic Ocean } \\
\hline MD99-2198 & $12.09^{\circ} \mathrm{N}, 61.23^{\circ} \mathrm{W}$ & 1330 & $\varepsilon_{\mathrm{Nd}}$ leachates (AAIW) & Pahnke et al. (2008) \\
\hline KNR166-2-26JPC & $24.33^{\circ} \mathrm{N}, 83.25^{\circ} \mathrm{W}$ & 546 & $\varepsilon_{\mathrm{Nd}}$ leachates (AAIW?) & Xie et al. (2012) \\
\hline MD07-3076 & $44.07^{\circ} \mathrm{S}, 14.21^{\circ} \mathrm{W}$ & 3770 & ${ }^{14} \mathrm{C}$ ventilation age (CDW) & Skinner et al. (2010) \\
\hline TNO57-6 & $42.92^{\circ} \mathrm{S}, 8,88^{\circ} \mathrm{E}$ & 3750 & Opal fluxes (CDW) & Anderson et al. (2009) \\
\hline RC11-83 & $41.07^{\circ} \mathrm{S}, 9.72^{\circ} \mathrm{E}$ & 4718 & $\varepsilon_{\mathrm{Nd}}$ leachates (NADW/AABW) & Piotrowski et al. (2004) \\
\hline \multicolumn{5}{|l|}{ Indian Ocean } \\
\hline VM19-188 & $6.87^{\circ} \mathrm{S}, 60.67^{\circ} \mathrm{E}$ & 3356 & $\varepsilon_{\mathrm{Nd}}$ leachates $(\mathrm{CDW})$ & Pahnke et al. (2008) \\
\hline
\end{tabular}

\section{Results and discussion}

\subsection{Planktonic foraminifera $\varepsilon_{N d}$ as a proxy for surface ocean variability}

At ODP Site 1240 the core-top $\varepsilon_{\mathrm{Nd}}$ value of -1.66 in cleaned thermocline dwelling $N$. dutertrei (Fig. 2) is identical to the closest published seawater $\varepsilon_{\mathrm{Nd}}$ values of -1.60 at $\sim 150 \mathrm{~m}$ depth in the EUC (Lacan and Jeandel, 2001), and higher than local deeper water values of $\sim-2.5$ (Piepgras and Wasserburg, 1980). Additionally, we have also measured the REE abundances in cleaned and uncleaned foraminiferal calcites in the same down-core samples used for $\varepsilon_{\mathrm{Nd}}$ analyses (Fig. 3). These are normalized to calcium (REE/Ca) and then to PAAS (Post-Archean Australian Shale, Taylor and McLennan, 1985). The Site 1240 cleaned foraminifera REE/Ca ratios show clear seawater-like patterns (Fig. 3a), with depletions in light REE and pronounced negative Ce anomalies. In contrast, unclean foraminifera REE/Ca ratios show shale-like patterns, with greater enrichment of the light REE and without clear Ce anomalies. On average, the REE/Ca ratios in the foraminiferal calcite are $\sim 200$ times higher than seawater $\left(K_{d} \sim 200\right)$, in good agreement with previously reported $\mathrm{REE} / \mathrm{Ca}$ abundances in cleaned foraminifera (Vance and Burton, 1999; Burton and Vance, 2000; Pomiès et al., 2002; Haley et al., 2005; Klevenz et al., 2008). Taking into account the estimated REE/Ca partition coefficient $\left(K_{d} \sim 200\right)$ between carbonates and seawater, and previously published $\varepsilon_{\mathrm{Nd}}$ and [Nd] values in the EEP for both thermocline (the EUC at $150 \mathrm{~m}$ depth, Lacan and Jeandel, 2001) and deep waters (Piepgras and Wasserburg, 1980), a simple mixing model strongly indicates that the $\varepsilon_{\mathrm{Nd}}$ measured in our cleaned foraminifera reflect the EUC (Fig. 2).

Studies of plankton tows report [Nd] averaging $0.11 \mathrm{ppm}$ (Pomiès et al., 2002), although cleaned core top foraminifera have shown [Nd] between 0.19-0.87 ppm (Vance et al., 2004). In this study, we used laser ablation ICP-MS to measure [Nd] in a transect through the foraminifera shell, in order to be able to distinguish $[\mathrm{Nd}]$ in the potentially contaminated innermost and outermost sections of the shell from 'clean' uncontaminated calcite in the center (Fig. 3b). Our results in $N$. dutertrei individual shells show that clean calcite has average [Nd] of $0.25 \mathrm{ppm}$, in agreement with solution ICP-MS measurements $(0.10-0.25 \mathrm{ppm})$ on cleaned foraminifera shells at Site 1240 (Fig. 3b). Based on these results, and the coincidence of our core top $\varepsilon_{\mathrm{Nd}}$ value $(-1.66)$ with EUC seawater measurements $(-1.60$, Lacan and Jeandel, 2001), as well as the offset from deep water $\varepsilon_{\mathrm{Nd}}$ values in the EEP ( - 2.5, Piepgras and Wasserburg, 1980), and taking into

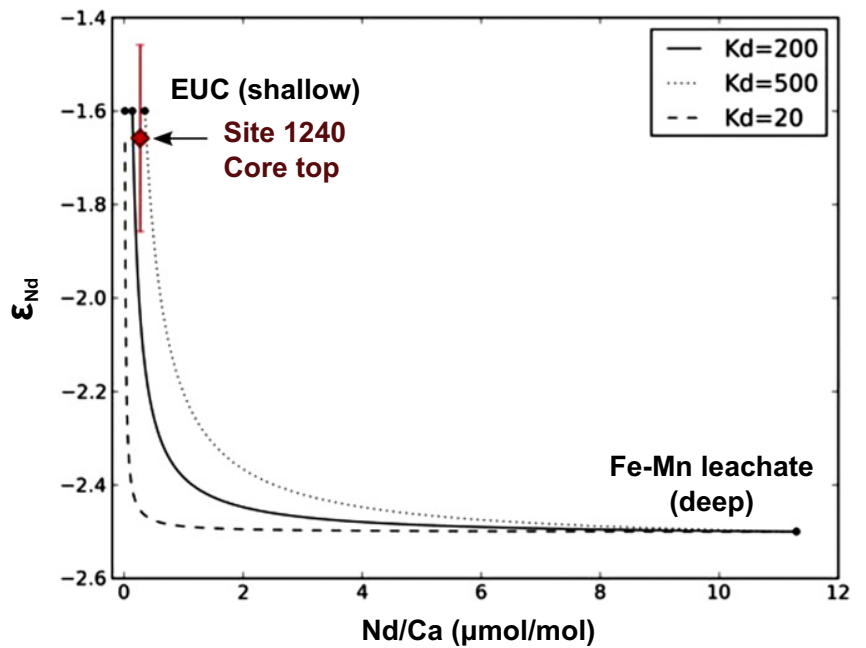

Fig. 2. Evaluation of the shallow vs. deep water $\varepsilon_{\mathrm{Nd}}$ signal, using core top $\varepsilon_{\mathrm{Nd}}$ and $\mathrm{Nd} / \mathrm{Ca}$ of cleaned planktonic foraminifera (red symbol) from Site 1240. Mixing curves are plotted using present day EUC $\left(\varepsilon_{\mathrm{Nd}}=-1.6 \pm 0.2\right.$, error is $2 \sigma$; $\mathrm{Nd} / \mathrm{Ca}=0.0007 \mu \mathrm{mol} / \mathrm{mol})$ and foraminiferal $\mathrm{Fe}-\mathrm{Mn}$ leachates $\left(\varepsilon_{\mathrm{Nd}}=-2.5\right.$, $\mathrm{Nd} / \mathrm{Ca}=11.5 \mu \mathrm{mol} / \mathrm{mol}$ ) ratios as shallow and deep water end-members, respectively. The $\varepsilon_{\mathrm{Nd}}$ values correspond to data on regional deep and EUC seawater (Piepgras and Wasserburg, 1980, Lacan and Jeandel, 2001). Expected Nd/Ca ratios in cleaned foraminifera are estimated for a range of partition coefficients $\left(K_{d}=20\right.$, 200,500 ) for foraminifera carbonates and seawater, using $[\mathrm{Ca}]=10.46 \mathrm{mmol} / \mathrm{kg}$. $\mathrm{Nd} / \mathrm{Ca}$ ratios for uncleaned $\mathrm{Fe}-\mathrm{Mn}$ oxide encrusted samples having the $\varepsilon_{\mathrm{Nd}}$ of the deep ocean end-member are estimated from the average of several analyses of uncleaned foraminifera. Regardless of the partition coefficient used, cleaned core top planktonic foraminifera at Site 1240 clearly yield a shallow seawater $\varepsilon_{\mathrm{Nd}}$ signal.

account the mixing systematics (Fig. 2), we conclude that $\varepsilon_{\mathrm{Nd}}$ measured on cleaned planktonic foraminifera at Site 1240 reflect the $\varepsilon_{\mathrm{Nd}}$ of surface ocean waters at the time these foraminifera were calcifying.

\subsection{EUC $\varepsilon_{N d}$ variability over the last $30 \mathrm{kyr}$}

The $N$. dutertrei $\varepsilon_{\mathrm{Nd}}$ results at ODP Site 1240 show significant variability in the EUC over the last $30 \mathrm{kyr}$ (Fig. 4a). Compared with Holocene $\varepsilon_{\mathrm{Nd}}$ values $(\sim-1.6)$, lower values $(\sim-2.5)$ are recorded during the Heinrich stadials 1 and 2 (HS1, 17.5-15 ka; HS2, $\sim 26-23 \mathrm{ka}$ ) and during the last glacial maximum (LGM, $\sim 21-$ $19 \mathrm{ka}$ ) (Fig. 4a). If we assume that the $\varepsilon_{\mathrm{Nd}}$ of SOIW remained constant, these lower $\varepsilon_{\mathrm{Nd}}$ values are consistent with increased 
a
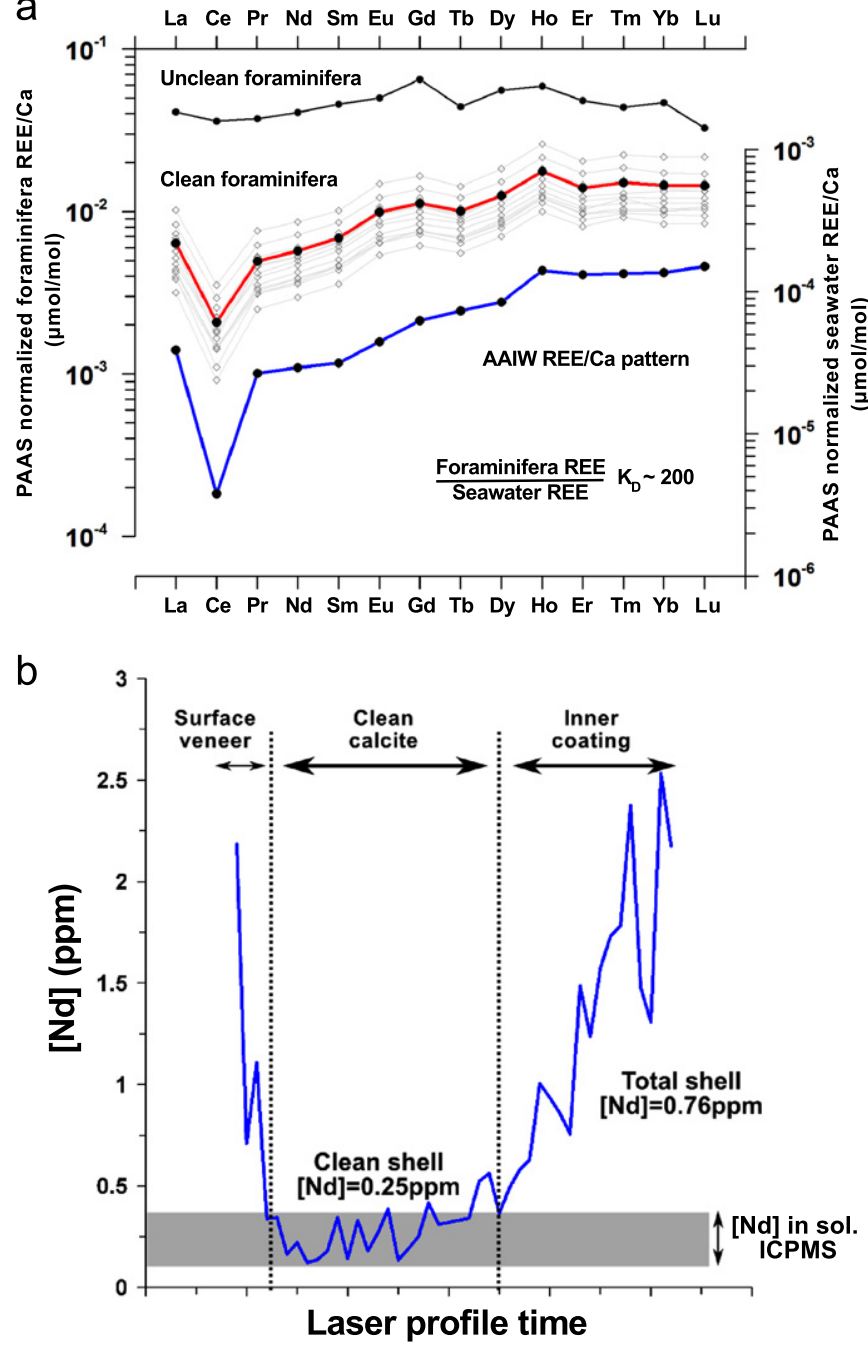

Fig. 3. (a) REE abundances in cleaned (red and gray lines) and uncleaned foraminifera (black line) samples at ODP Site 1240. The red line shows the average REE pattern for cleaned foraminifera measured down-core, the gray lines show individual REE patterns. Cleaned foraminifera clearly show a seawater-like pattern. A REE pattern for AAIW is shown for comparison (Piepgras and Jacobsen, 1992). The foraminifera REE concentrations are normalized to $\mathrm{Ca}(\mu \mathrm{mol} / \mathrm{mol})$ and the AAIW values normalized to Ca assuming $10.46 \mathrm{mmol} / \mathrm{L}$ Ca for seawater. The REE/Ca values are normalized to PAAS (Post-Archean Australian Shale, Taylor and McLennan, 1985). Average partition coefficient $\left(K_{d}\right)$ estimated for the REE/Ca in foraminifera is $\sim 200$ times seawater, the same order of magnitude as other published foraminifera REE data under very different hydrographic conditions (Burton and Vance, 2000; Klevenz et al., 2008; Pomiès et al., 2002; Vance and Burton, 1999). (b) Nd concentration profile through an uncleaned foraminifera shell measured by laser ablation ICPMS. Three different intervals are clearly distinctive: surface veneer, clean calcite and inner coating. Gray shaded area illustrates the range of [Nd] measured on cleaned foraminifera by solution ICPMS. (For interpretation of the references to colour in this figure legend, the reader is referred to the web version of this article.)

advection of SOIW to the EUC during HS2, the LGM, and HS1. At $\sim 15 \mathrm{ka}$, coinciding with the Bølling-Allerød (B-A), the EUC waters show the highest values $\left(\varepsilon_{\mathrm{Nd}} \sim-1\right)$, consistent with reduced SOIW transport to the tropical thermocline. Following the B-A, there is a return to lower values $\left(\varepsilon_{\mathrm{Nd}} \sim-2.7\right)$ between 12 and $9 \mathrm{ka}$, during the PreBoreal-Younger Dryas (PB-YD) time interval, which is followed by an increase towards the Holocene. The minimum EUC $\varepsilon_{\mathrm{Nd}}$ values at Site 1240 following the B-A period are also consistent with intensification of the EUC and tropical upwelling, as previously reported (Pena et al., 2008a; Pena and Cacho, 2009). A reinvigorated EUC during the PB-YD is expected

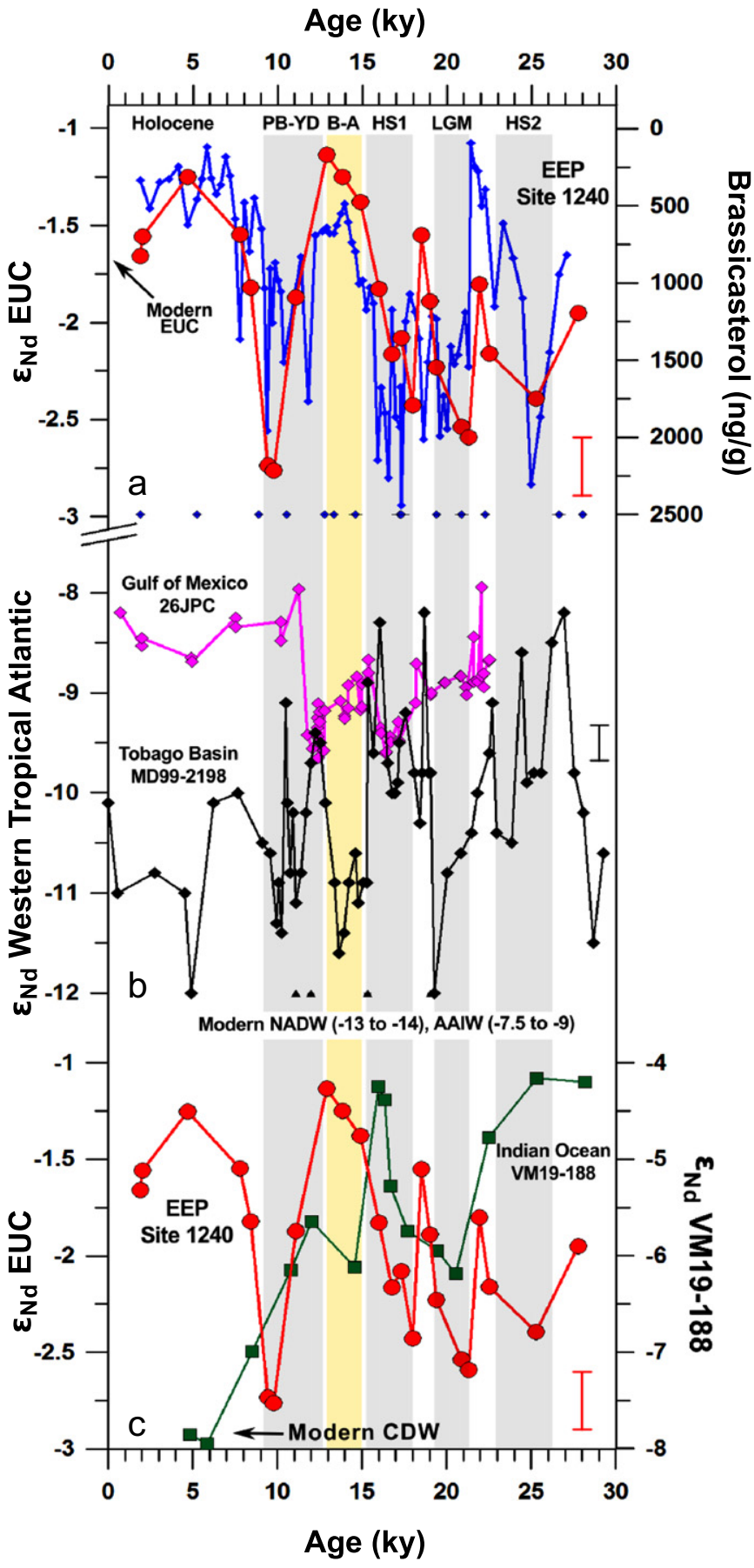

Fig. 4. (a) Foraminiferal EUC $\varepsilon_{\mathrm{Nd}}$ (red) and brassicasterol concentration (blue) at Site 1240 for the last $30 \mathrm{kyr}$. The age model for Site 1240 is based on $13{ }^{14} \mathrm{C}$-ages (blue diamonds; Pena et al., 2008a). (b) Sediment Fe-Mn oxide leachate $\varepsilon_{\mathrm{N}}$ records of an intermediate depth core from the Tobago Basin, WTA (MD99-2198, 1330 m, black diamonds; from Pahnke et al., 2008) and a shallow core from the Gulf of Mexico (KNR166-2-26JPC, 546 m, purple diamonds; Xie et al., 2012). Both cores converge to similar $\varepsilon_{\mathrm{Nd}}$ values during HS1 and the YD, consistent with strong AAIW during those cold intervals. (c) Nd isotope record from core VM19-188 in the Indian Ocean (green), used here as a proxy for the Southern Ocean Nd endmember. Vertical shaded bars correspond with Preboreal-Younger Dryas (PB-YD), Bølling-Allerød (B-A), Last Glacial Maximum (LGM) and Heinrich Stadials 1 and 2 (HS1, HS2). Vertical error bars correspond with typical total $( \pm 2 \sigma)$ error for both $\varepsilon_{\mathrm{Nd}}$ records.

to transport more SOIW towards the EEP, consistent with the observed lower $\varepsilon_{\mathrm{Nd}}$ values (Fig. 4a).

In order to test our interpretation that $\varepsilon_{\mathrm{Nd}}$ in thermocline dwelling foraminifera trace changes in the advection of SOIW, we 
have compared the EUC $\varepsilon_{\mathrm{Nd}}$ record with brassicasterol concentrations on the same sediment samples used in this study at Site 1240 (Calvo et al., 2011). Brassicasterol is an organic biomarker in the sediments, which is closely associated with the abundance of diatoms and cocolitophorids in the water column (Werne et al., 2000; Calvo et al., 2004). In the modern ocean, the EEP is silicalimited (Pichevin et al., 2009), which makes it difficult for silica dependent organisms (e.g. diatoms) to bloom and compete with carbonate-shelled organisms (like coccolithophore algae and foraminifera). However, increased contributions of SOIW into the EUC, with higher dissolved Si concentrations, would both stimulate the diatom production, resulting in higher brassicasterol/ alkenones ratios in the sediments, and shift EUC $\varepsilon_{\mathrm{Nd}}$ towards more negative Southern Ocean values. Fig. 4a clearly illustrates that periods of relatively high brassicasterol concentration closely correspond with low EUC $\varepsilon_{\mathrm{Nd}}$ values at Site 1240.

Pahnke et al. (2008) measured the $\varepsilon_{\mathrm{Nd}}$ of Fe-Mn oxide leachates over the last $30 \mathrm{kyr}$ (Fig. 4b) from an intermediate water depth core in the Tobago Basin, western tropical Atlantic (WTA) (MD99-2198, $1330 \mathrm{~m}$, Fig. 1, Table 2). This site is located near the upper limit of modern NADW and the transition to AAIW (Supplementary Fig. S1), making it very sensitive to changes in the relative influences of NADW vs. SOIW. Pahnke et al. (2008) interpreted the $\varepsilon_{\mathrm{Nd}}$ increases in the Tobago Basin record as reflecting increases in the influence of AAIW at the core site, in particular during the HS2, HS1 and YD intervals. A recent shallow LGM to Holocene record by Xie et al. (2012) from the Florida shelf in the Gulf of Mexico (KNR166-2-26JPC, 546 m, Fig. 1, Table 2), from the LGM to the Holocene, also shows significant excursions toward similar $\varepsilon_{\mathrm{Nd}}$ values during HS1 and the PB-YD (Fig. 4b). These results are consistent with an increased flux of the same southern-sourced intermediate water component observed by Pahnke et al. (2008) into the Gulf of Mexico.

We note that Xie et al. (2012) come to the opposite conclusion (that HS1 and the PB-YD show decreased AAIW signals). A full discussion of the issues is beyond the scope of the main text here, but a more extensive one is included in the Supplementary Materials. The primary assumption by Xie et al. (2012) is that AAIW, only slightly modified from its end-member composition in the Southern Ocean, is the dominant water mass at the Gulf of Mexico site in the present-day (and much of the past), which is not supported by present-day hydrographic data (Supplementary Fig. S1). We follow the Pahnke et al. (2008) interpretation here because the present-day water mass at the Tobago Basin site is modified NADW, the site is overlain by modified AAIW (Fig. S1), and the interpretation through time is more straightforward to reconcile with our knowledge of the evolution of northern- and southern-sourced water masses.

The patterns of $\varepsilon_{\mathrm{Nd}}$ variability over the last $30 \mathrm{kyr}$ are similar in the Tobago Basin (MD99-2198) and EEP (ODP Site 1240) records (Fig. $4 \mathrm{~b}$ and $\mathrm{c}$ ). Positive $\varepsilon_{\mathrm{Nd}}$ excursions in the Tobago Basin record often took place synchronously (within the dating uncertainties) with negative $\varepsilon_{\mathrm{Nd}}$ excursions (and brassicasterol concentration maxima) in the EEP. Since the equatorial Pacific has higher $\varepsilon_{\mathrm{Nd}}$ values than the Southern Ocean, and the tropical Atlantic has lower values, we infer that both sites converged simultaneously towards Southern Ocean $\varepsilon_{\mathrm{Nd}}$ values, consistent with an increased export of SOIW towards higher latitudes during cold periods (HS2, HS1, LGM and PB-YD) and a decreased export during warm intervals (B-A and Holocene). As expected, the amplitude of the $\varepsilon_{\mathrm{Nd}}$ excursions is larger at the Tobago Basin site $\left(\sim 2-3 \varepsilon_{\mathrm{Nd}}\right.$ units) due to its depth near a hydrographic front (Fig. S1) between NADW and AAIW (present-day end-member $\varepsilon_{\mathrm{Nd}}$ of -13 to -14 and -7 to -6 , respectively). At Site 1240 the EUC $\varepsilon_{N d}$ record shows relatively smaller excursions ( $\sim 1.5$ to $2 \varepsilon_{\mathrm{Nd}}$ units), reflecting the longer route that SOIW takes to reach the EEP and overall greater REE concentrations in Pacific waters (Fig. 1). Prior to estimating the volume transport of SOIW, we need to consider other factors, such as the stability of the source end-member $\varepsilon_{\mathrm{Nd}}$ values for the last $30 \mathrm{kyr}$, and the potential impact of boundary exchange processes.

\subsection{Effects of boundary exchange}

The EUC formation area in the western equatorial Pacific is located north of Papua New Guinea (Fig. 1), and is formed from mixing of mostly Southern Hemisphere waters (Tsuchiya et al., 1989; Tsuchiya, 1991), including SAMW-AAIW (Toggweiler et al., 1991; Rodgers et al., 2003; Goodman et al., 2005). High $\varepsilon_{\text {Nd }}$ values ( -1.60$)$ measured in the EUC at $150 \mathrm{~m}$ depth were interpreted by Lacan and Jeandel (2001) as a result of boundary exchange processes in the EUC formation zone north of PNG, which sheds detritus typically with high $\varepsilon_{\mathrm{Nd}}(\sim+7)$. Lacan and Jeandel (2001) also concluded that slightly elevated dissolved $[\mathrm{Nd}]$ in the lower EUC $(\sim 6.6 \mathrm{pmol} / \mathrm{kg})$ compared to the upper layers $(\sim 4.9 \mathrm{pmol} / \mathrm{kg})$ indicate extra $\mathrm{Nd}$ input from PNG through boundary exchange. However, even if $\mathrm{Nd}$ from PNG is having some impact on the $\varepsilon_{\mathrm{Nd}}$ signature in EUC waters, it is unlikely that the $\varepsilon_{\mathrm{Nd}}$ of PNG sources have changed over the past $\sim 30 \mathrm{kyr}$. Neither is there any reason to expect that the EUC $\varepsilon_{\mathrm{Nd}}$ signal would change over the past $30 \mathrm{kyr}$ due to changes in the boundary exchange conditions at PNG, as our measurements of REE patterns in the foraminifera samples at Site 1240 do not show any changes in their seawater REE patterns (Fig. 3a). Additionally, the strong correspondence between the EUC $\varepsilon_{\mathrm{Nd}}$ record and the biomarker (brassicasterol) concentrations in the sediments, linked primarily to diatom productivity, strongly suggests a Southern Ocean water mass effect on the $\varepsilon_{\mathrm{Nd}}$ signal at this site. Moreover, if enhanced boundary exchange caused increased diatom productivity in the EEP (for example, driven by increasing the amount of dissolved iron in the EUC waters; Wells et al., 1999), this would cause the EUC to show more positive $\varepsilon_{\mathrm{Nd}}$, contrary to the observed pattern at Site 1240 (Fig. 4a). Therefore, we conclude that changes in the $\varepsilon_{\mathrm{Nd}}$ of the EUC are intrinsically linked to variations in the volume transport of SOIW, or to changes in Southern ocean $\varepsilon_{\mathrm{Nd}}$ end-member, rather than to any effects from PNG boundary exchange processes.

\subsection{EUC $\varepsilon_{N d}$ : Southern ocean advection vs. end-member variability}

Several studies indicate that the deep-ocean North Atlantic and North Pacific $\varepsilon_{\mathrm{Nd}}$ end-members have remained unchanged on glacial-interglacial and millennial timescales $\left(\varepsilon_{\mathrm{Nd}} \sim-14\right.$ to -13 and -4 to 0 respectively; Abouchami et al., 1997, Rutberg et al., 2000, van de Flierdt et al., 2006; Foster et al., 2007). This is not the case for the Southern Ocean, where the present day $\varepsilon_{\mathrm{Nd}}$ of deep waters $(\sim-8$ to -9$)$ approximates the mixing of North Atlantic and Pacific end-members. In the absence of additional external inputs, a deep North Pacific $\varepsilon_{\mathrm{Nd}}$ of -4 (Piepgras and Jacobsen, 1988) and deep North Atlantic $\varepsilon_{\mathrm{Nd}}$ of -13.5 (Piepgras and Wasserburg, 1987) imply that $\sim 55 \%$ of the $\mathrm{Nd}$ in the Drake Passage comes from the North Atlantic. Decreased southward export of NADW during cold climate intervals resulted in more positive $\varepsilon_{\mathrm{Nd}}$ in Southern Ocean waters, as shown by studies of Cape Basin sediments (Rutberg et al., 2000; Bayon et al., 2004; Piotrowski et al., 2004, 2005) and deep sea corals from the Drake Passage (Robinson and van de Flierdt, 2009). Therefore, changes in the Southern Ocean $\varepsilon_{\mathrm{Nd}}$ need to be taken into account in SOIW flux estimates. Pahnke et al. (2008) faced this problem in their study of Nd isotopes at intermediate water depths in the WTA over a similar time period, and used the $\varepsilon_{\mathrm{Nd}}$ record of core VM19188 from the Indian Ocean (Fig. 1, Table 2) as a proxy for the 
Southern Ocean $\varepsilon_{\mathrm{Nd}}$ variability over the last $30 \mathrm{kyr}$ (Fig. 4c). VM19-188 is bathed by Circumpolar Deep Water (CDW) and its core-top $\varepsilon_{\mathrm{Nd}}$ value matches typical Southern Ocean values as well as modern seawater $\varepsilon_{\mathrm{Nd}}$ at that location. Its $\varepsilon_{\mathrm{Nd}}$ changed through time (Fig. 4c), with more positive $\varepsilon_{\mathrm{Nd}}$ values (more Pacific-like) before $22 \mathrm{ka}$ (HS2) and between $\sim 15$ and $17 \mathrm{ka}$ (HS1), when the formation and export of NADW was significantly weaker than in the present day, and more Atlantic-like $\varepsilon_{\mathrm{Nd}}$ values during the LGM (Fig. 4c), likely indicating an increased southward export of glacial-mode North Atlantic intermediate waters (GNAIW) (Adkins et al., 1997; Curry and Oppo, 2005). The Indian Ocean site was used because of problems in finding Southern Ocean cores that yield marine $\varepsilon_{\mathrm{Nd}}$ (Piotrowski et al., 2008). Pahnke et al. (2008) assumed that down-core $\varepsilon_{\mathrm{Nd}}$ offsets from modern seawater in VM19-188 reflect changes in the Southern Ocean $\varepsilon_{\mathrm{Nd}}$ end-member, and subtracted these offsets from their measured $\varepsilon_{\mathrm{Nd}}$ values in their WTA record.
In this study we used a similar approach in order to determine if the variability in the EUC $\varepsilon_{\mathrm{Nd}}$ record at Site 1240 is a result of changes in the export of SOIW or changes in the Southern Ocean $\varepsilon_{\mathrm{Nd}}$ value. We used a two end-member mixing model in order to estimate changes in transport of SOIW into the EUC for the last $30 \mathrm{kyr}$ (the Supplementary Materials include the present-day end-member water mass compositions in Table S1, as well as a further explanation of the mixing model). Like Pahnke et al. (2008), we assume that the variability of Southern Ocean $\varepsilon_{\mathrm{Nd}}$ through time is reflected by VM19-188 (Figs. 4c, 5b and d, 6c). Because there is a difference of $\sim 1-2 \varepsilon_{\mathrm{Nd}}$ units between CDW $\left(\varepsilon_{\mathrm{Nd}} \sim-8\right.$ to -9$)$ and $\operatorname{SOIW}\left(\varepsilon_{\mathrm{Nd}}=-6\right.$ to -7$)$ in the modern Southern Ocean, we compensate for this difference by assuming that SOIW is $2 \varepsilon_{\mathrm{Nd}}$ units more positive than the VM19-188 record through time. The $\varepsilon_{\mathrm{Nd}}$ of the EEP end-member assumes a constant value of $\varepsilon_{\mathrm{Nd}}=-0.85$, after correcting the measured modern value of $\varepsilon_{\mathrm{Nd}}=-1.6$ (Lacan and Jeandel, 2001) for the contribution of a

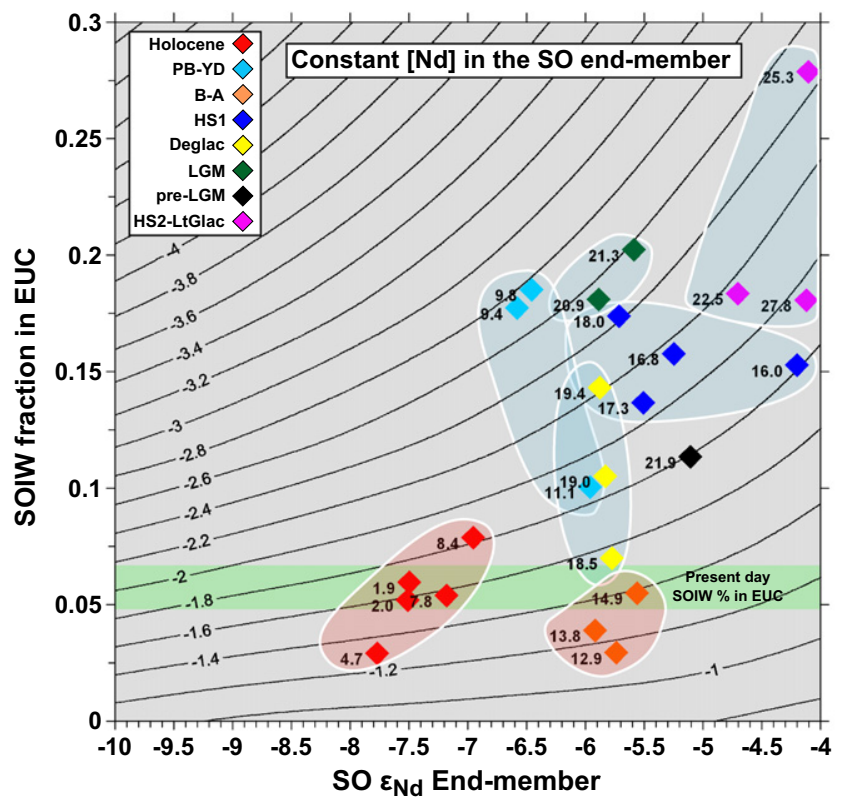

b

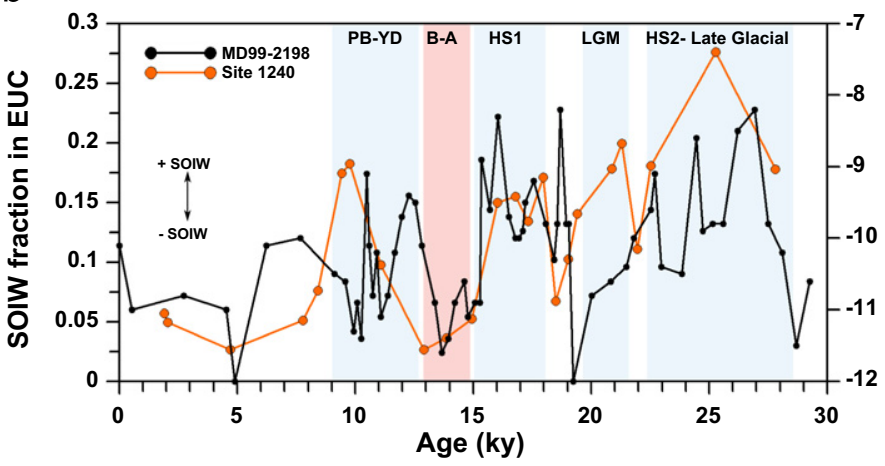

C

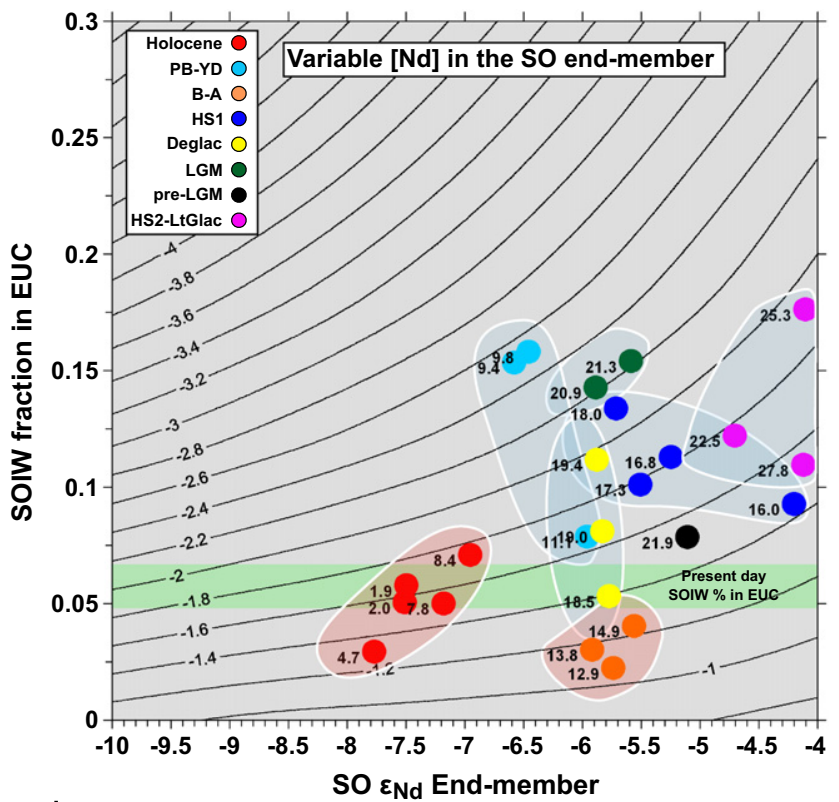

d

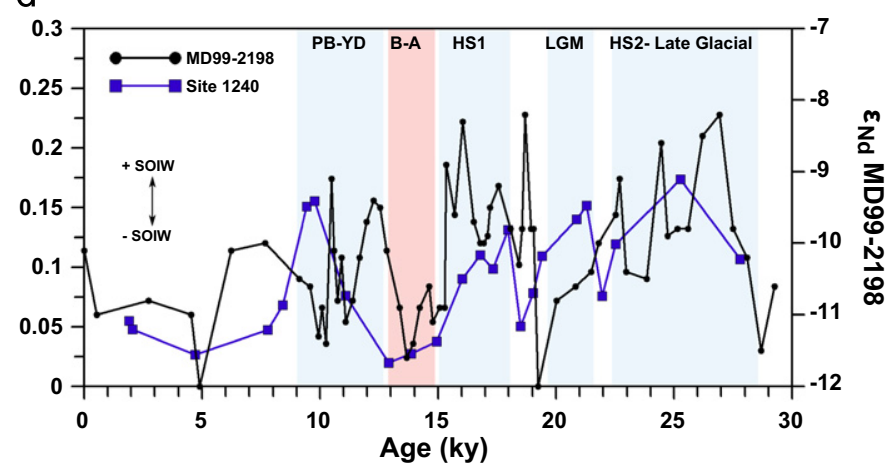

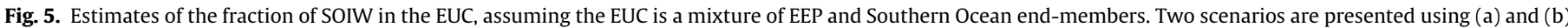

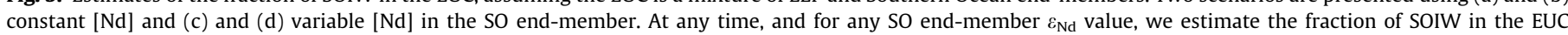

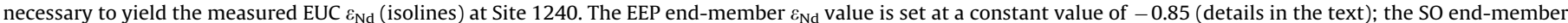

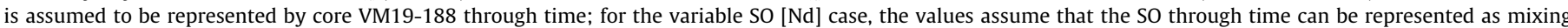

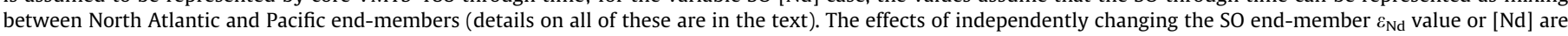

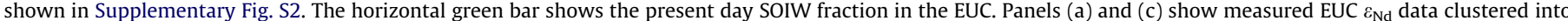

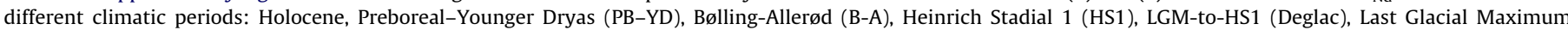

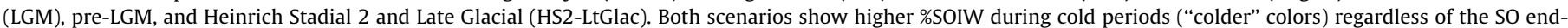

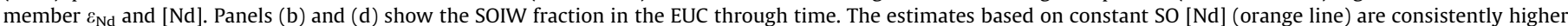

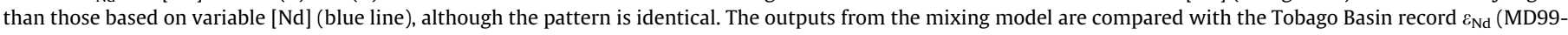

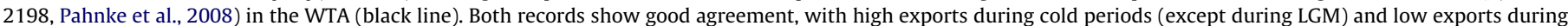
warm periods. 
SOIW to the present day EUC ( $\sim 5 \%$; Goodman et al., 2005). [Nd] in the SOIW end-member is defined by typical Southern Ocean intermediate water values (17 pmol/kg; German et al., 1995), and

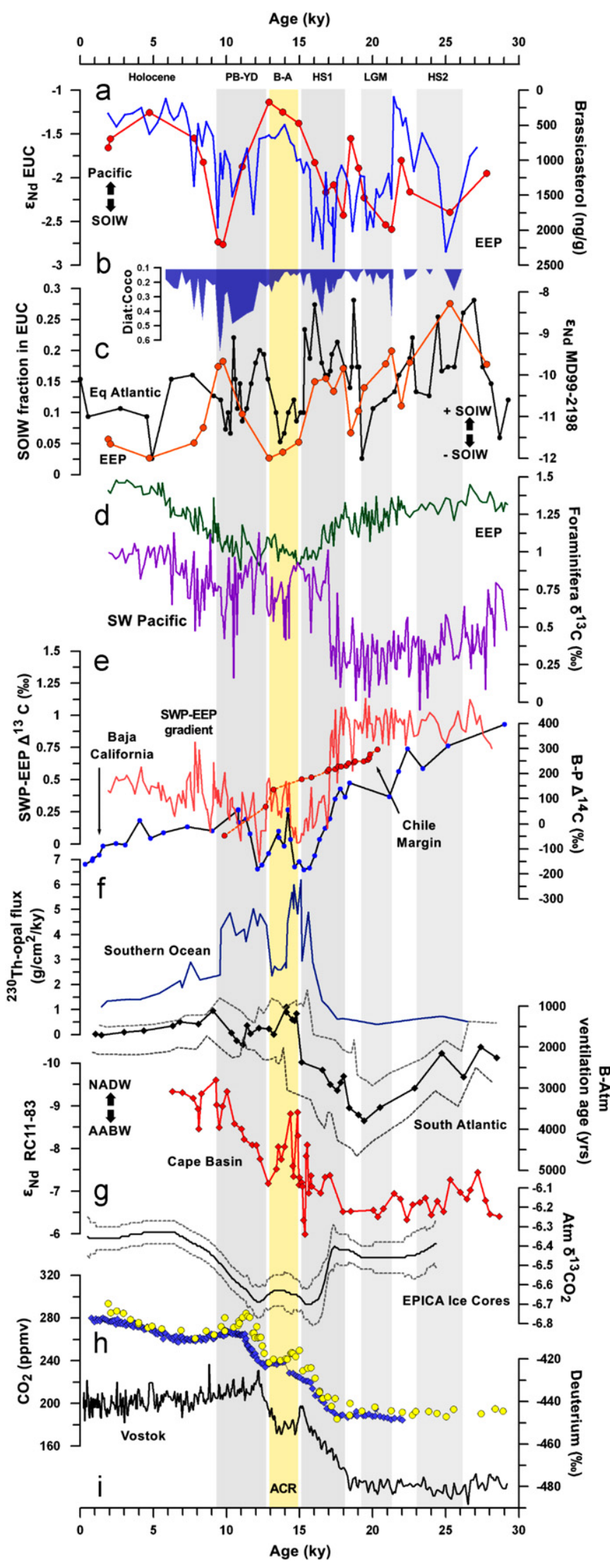

in the EEP end-member by EEP waters near the EUC ( $7 \mathrm{pmol} / \mathrm{kg}$; Lacan and Jeandel, 2001). Using these values, along with EUC $\varepsilon_{\mathrm{Nd}}$ at Site 1240, we estimated the fraction of SOIW in the EUC (Fig. 5a; the way we constructed Fig. 5a and $\mathrm{c}$ is further illustrated in Supplementary Fig. S2). This approach allowed us to obtain first order estimates of the changes in the SOIW advection to the tropical Pacific, while compensating for the variability of $\varepsilon_{\mathrm{Nd}}$ in the Southern Ocean.

The results of the calculation indicate that during relatively warm climatic periods (Holocene and Bølling-Allerød), the fraction of SOIW in the EUC was similar to, or slightly lower than, the present day ( $\sim 5 \%$; Fig. 5a and $b$ ). However, during cold periods (YD, LGM, HS1 and HS2) the calculation indicates larger export of SOIW towards the tropics ( $\sim 10-25 \%$; Fig. 5a and b). During the LGM and HS1 the estimated variability is small ( $\sim 15-20 \%$ and $\sim 16-17 \%$ respectively), probably reflecting relatively stable climate during these intervals, while during rapid climatic transitions (e.g. the onset of deglaciation and the PB-YD transition) the variability is greater ( $\sim 6-17 \%$ and $\sim 3-18 \%$ respectively). The results obtained here, with increased export of SOIW during some intervals (comprising up to $\sim 25 \%$ of the EUC water), agree very well with estimates of AAIW export for the same time period by Pahnke et al. (2008), comprising up to $30 \%$ of the intermediate water at the Tobago Basin site.

In order to further test the sensitivity of our model we also allowed $[\mathrm{Nd}]$ to vary in the Southern Ocean end-member (Fig. $5 \mathrm{c}$ and d; details are in the Supplementary Materials). Because modern Southern Ocean [Nd] reflects mixing between North Atlantic and North Pacific deep waters (Piepgras and Wasserburg, 1982; Tazoe et al., 2006; Carter et al., 2012), we expect that changes in their relative contributions over the last $30 \mathrm{kyr}$ should impact [Nd] as well as $\varepsilon_{\mathrm{Nd}}$ in the Southern Ocean end-member. The estimation of $[\mathrm{Nd}]$ in the Southern Ocean through time uses the North Atlantic (NADW: $17 \mathrm{pmol} / \mathrm{kg}, \varepsilon_{\mathrm{Nd}}=-13.5$ ) and North Pacific (PDW: $40 \mathrm{pmol} / \mathrm{kg}$ and $\varepsilon_{\mathrm{Nd}}=-4$ ) end-members, and assumes that the $\varepsilon_{\mathrm{Nd}}$ of the Southern Ocean at any time reflects binary mixing. This approach is justified by present-day observations; if the deep Southern Ocean $\varepsilon_{\mathrm{Nd}}$ value of $\sim-8$ reflects mixing of these two end-members, the estimated [Nd] $(26.5 \mathrm{pmol} / \mathrm{kg})$ matches modern CDW measurements from the Southeast Pacific (20-30 pmol/ $\mathrm{kg}$; Carter et al., 2012, Stichel et al., 2012). Because Southern Ocean [Nd] profiles consistently show a difference of $10 \mathrm{pmol} / \mathrm{kg}$ between

Fig. 6. Comparison of proxy records over the last $30 \mathrm{kyr}$ that indicate meridional export of SOIW towards the tropics. Details on the locations and the depths of the records are in Fig. 1 and Table 2. (a) EUC $\varepsilon_{\mathrm{Nd}}$ (red line, this study) and brassicasterol concentration (blue line, Calvo et al., 2011) at Site 1240. (b) Diatom:coccolithophore ratio (shaded blue) indicating intervals of high and low $\mathrm{SiO}_{2}$ (reflected by diatom productivity) in the EEP (Calvo et al., 2011). (c) SOIW fraction in the EUC from Fig. $5 \mathrm{~b}$ (orange line) plotted along with the $\varepsilon_{\mathrm{Nd}}$ of Fe-Mn oxide leachates in the WTA core MD99-2198 (Pahnke et al., 2008). (d) N. dutertrei (green line) and benthic foraminifera (purple line) $\delta^{13} \mathrm{C}$ at Site 1240 and MD972120 (southwest Pacific, SWP, Pahnke et al., 2005). (e) Calculated EEP-SWP $\Delta{ }^{13} \mathrm{C}$ gradient between the two records in panel (d) (pink line), together with the paired benthic-planktonic foraminifera apparent ventilation ages (B-P $\Delta^{14} \mathrm{C}$ ) off Baja California (blue circles, Marchitto et al., 2007) and the Chile Margin (red circles, De Pol-Holz et al., 2010). (f) Opal fluxes $\left({ }^{230}\right.$ Th normalized) in core South Atlantic core TN057-13-4PC (blue line, Anderson et al., 2009) as a proxy for upwelling south of the Antarctic Polar front (Fig. 1), and the apparent deep-ocean ventilation age (B-P $\Delta^{14} \mathrm{C}$ ) in South Atlantic core MD07-3076 (black dots, Skinner et al., 2010). (g) $\varepsilon_{\mathrm{Nd}}$ in Fe-Mn oxide leachates of South Atlantic core RC11-83 (red dots, Piotrowski et al., 2004) reflecting NADW vs. AABW strength at this site in the Cape Basin, and the atmospheric $\delta^{13} \mathrm{CO}_{2}$ in a stack of EPICA ice cores (black line, Schmitt et al. 2012). (h) $\mathrm{CO}_{2}$ at Siple Dome (blue diamonds, Ahn et al., 2004) and Dome $\mathrm{C}$ (yellow circles, Monnin et al., 2001) ice cores, Antarctica. (i) Vostok deuterium isotopes (black line, Jouzel et al., 1987). Vertical shaded bars indicate timing of North Atlantic event-stratigraphy chronozones: Holocene, Preboreal-Younger Dryas (PB-YD), Bølling-Allerød (B-A), Antarctic Cold Reversal (ACR), Last Glacial Maximum (LGM) and Heinrich Stadials 1 and 2 (HS1, HS2). 
intermediate waters and CDW (Carter et al., 2012, Stichel et al., 2012), we have applied this as a correction factor through time. The estimate of the $\varepsilon_{\mathrm{Nd}}$ variability of the SOIW end-member through time uses the VM19-188 record in the same way as the constant $[\mathrm{Nd}]$ calculation. Compared to the constant [Nd] calculation (i.e. Fig. 5a and b), the overall pattern of the SOIW export to the tropical Pacific remains unchanged, with increased export during cold intervals, and decreased export rates during warm intervals (Fig. $5 c$ and d). However, the absolute amounts of SOIW exported are different than in the constant [Nd] calculation, because when the Southern Ocean end-member is more like the North Pacific, it has higher [Nd]. Thus, the variable [Nd] calculation requires less total export of SOIW to explain the $\varepsilon_{\mathrm{Nd}}$ changes in the EUC during these time periods. This is especially clear during HS1 and HS2, when the VM19-188 $\varepsilon_{\mathrm{Nd}}$ record approaches deep North Pacific $\varepsilon_{\mathrm{Nd}}$ values (Fig. 4c). Nevertheless, even during cold periods, the variable $[\mathrm{Nd}]$ calculation indicates significant increases in the volume of SOIW transported to the EUC, comprising up to $18 \%$ of EUC water during HS2.

\subsection{Transfer of climatic signals through SOIW advection}

The estimated changes in SOIW meridional transport at ODP Site 1240 suggest increased export during colder climatic periods (YD, HS1, LGM and HS2), when the southward transport of NADW was markedly weaker than today. There is abundant proxy evidence suggesting that reduced North Atlantic overturning was accompanied by increased meridional export of AAIW into the Atlantic Ocean during Heinrich events and the Younger Dryas interval (Zahn et al., 1997; Keeling and Stephens, 2001; Saenko et al., 2003; McManus et al., 2004; Timmermann et al., 2007; Makou et al., 2010). The results obtained at Site 1240 support these conclusions and confirm that the same compensation mechanism (i.e. stronger AAIW when northern-sourced water export is weak) was also active in the Pacific sector of the Southern Ocean. Detailed comparison of the SOIW export changes for the last $30 \mathrm{kyr}$ in the WTA (Pahnke et al., 2008) and the tropical Pacific (this study) clearly indicates a tight coupling between the meridional exports in both basins (Figs. 5d and 6c), thus reinforcing the importance of these intermediate water masses as sensitive gauges for rapid climate changes as well as feasible mechanisms for the transfer of climatic signals from high latitudes towards tropical regions. There are, nevertheless, some discrepancies between the records, particularly during the LGM (19-21 ka), when the WTA record indicates a minimum in AAIW export into the North Atlantic, whereas the Pacific record indicates increased export of SOIW (comprising $\sim 15-20 \%$ of EUC water) into the tropical Pacific (Figs. 5c and 6c). These differences might be explained by enhanced formation and southward export of GNAIW (Boyle and Keigwin, 1987; Curry and Oppo, 2005), which would displace AAIW southward in the tropical Atlantic record while AAIW is still present in the tropical Pacific. This is in agreement with a new ${ }^{231} \mathrm{~Pa} /{ }^{230} \mathrm{Th}$ dataset from glacial Atlantic sediments that indicate strong convection of (shallow) GNAIW during the LGM (Lippold et al., 2012). Several studies have also shown stronger North Pacific Intermediate water (NPIW) formation during the LGM (Keigwin, 1998; Ohkushi et al., 2003; Horikawa et al., 2011), but the evidence also indicates that NPIW formation was confined into the far North Pacific during this time period (Keigwin, 1998). Thus, unlike in the tropical Atlantic, with relatively strong GNAIW convection, there is no glacial NPIW counterpart with significant southward export that could replace SOIW in the tropical Pacific during the LGM, as indicated by the data presented here (Figs. 5d and 6c). It has been also suggested that southward transport of GNAIW would be accompanied by reduced formation of AAIW during the LGM, based on benthic foraminifera $\delta^{13} \mathrm{C}$ records from the southwest Pacific (Pahnke and Zahn, 2005). However our EUC $\varepsilon_{\mathrm{Nd}}$ results indicate that the northward advection of SOIW was still active in the Pacific Ocean during the LGM, consistent with recent results from the South Atlantic indicating basin wide AAIW northward penetration to at least $27^{\circ} \mathrm{S}$ (Makou et al., 2010).

The observed reversed phasing at millennial timescales between meridional export of SOIW and NADW provides strong support to the inter-hemispheric seesaw (Broecker, 1998, Ganopolski and Rahmstorf, 2001; Keeling and Stephens, 2001; Saenko et al., 2003). According to these models, the Atlantic overturning circulation displays three qualitatively different steady states. The "warm" mode is similar to the present-day Atlantic circulation with strong export of NADW. The "cold" or "glacial on" mode is characterized by export of GNAIW at shallower depths than NADW. Finally, the "glacial off" mode occurs without significant formation of NADW or GNAIW. The "glacial off" mode appears to have occurred after major inputs of freshwater, either from extended glacial ice sheets (e.g. Heinrich events) or meltwater floods from the continents (e.g. YD). The data presented here further support the existence of these circulation states during the last deglaciation. During the 'glacial on' mode (e.g. the LGM) intermediate depth convection of GNAIW carried a North Atlantic $\varepsilon_{\mathrm{Nd}}$ signal southward into the tropical regions (as indicated by low $\varepsilon_{\mathrm{Nd}}$ values in the WTA record in Fig. 4b), displacing AAIW southward at this latitude. On the other hand, in the Pacific Ocean, the absence of any significant intermediate water equivalent to GNAIW allowed for the presence of SOIW, with a Southern Ocean $\varepsilon_{\mathrm{Nd}}$ signal. In the "glacial off" mode (e.g. HS1, YD), the reduced density of Atlantic ocean surface waters resulting from the freshwater pulse shut down the formation of NADW and GNAIW in the North Atlantic. This collapsed state would have required a substantial volume of the ocean to be filled with intermediate and deep waters formed around Antarctica. This northward expansion of southern ocean intermediate waters is consistent with the stronger Southern Ocean-like $\varepsilon_{\mathrm{Nd}}$ signals during HS1 and the YD in both the tropical Atlantic and Pacific intermediate water records (Fig. 5d). In the deep ocean it is consistent with South Atlantic records showing $\varepsilon_{\mathrm{Nd}}$ signals indicating enhanced Antarctic Bottom Water (AABW) during Heinrich events (Piotrowski et al., 2004, 2005). While the $\varepsilon_{\mathrm{Nd}}$ data demonstrate a strong link between SOIW and climate changes in the North Atlantic and Pacific, it does not allow us to identify the ultimate driver of these variations, that is, whether changes in SOIW production reflect a direct response to Southern Hemisphere warming during North Atlantic cold periods (i.e. the bipolar seesaw) or a passive response to changes in North Atlantic convection. Our results are consistent with either or both mechanisms occurring during the last $30 \mathrm{kyr}$.

\subsection{Implications for the role of the Southern Ocean during the deglaciation}

The rapid and transient $\varepsilon_{\mathrm{Nd}}$ excursions toward more negative values in the tropical Pacific (and toward more positive values in the tropical Atlantic) during the last $30 \mathrm{kyr}$ suggest increased export of SOIW towards lower latitudes during cold climatic periods. This idea is reinforced in the tropical Pacific by the close correlation of $\varepsilon_{\mathrm{Nd}}$ negative excursions and increased concentration of brassicasterol in the sediments (Fig. 6a), which, when compared to coccolithophorid derived long chain alkenones, indicates increased productivity of diatoms vs. coccolithophores (Werne et al., 2000; Calvo et al., 2004) during these time periods. In a recent study, Calvo et al. (2011) defined the "diatoms:coccolithophores index" (the total concentration of brassicasterol over the summation of brassicasterol and 
alkenones concentrations) as a 'diatom-bound' productivity proxy in the EEP. Our results (Fig. 6b) suggest that the negative $\varepsilon_{\mathrm{Nd}}$ excursions during HS1 and the YD were accompanied by large silica exports from the Southern Ocean into the EEP (a silicalimited region; Pichevin et al., 2009), resulting in increased diatom productivity over coccolithophores. This interpretation is also supported by a recent Th-normalized opal flux record from the Atlantic sector in the Southern ocean (Fig. 6f) that confirms large increases in opal flux during HS1 and the YD (Anderson et al., 2009). Increased meridional export of silica-rich intermediate waters from the Southern Ocean towards the tropics would stimulate diatom productivity in otherwise silica-limited regions (Calvo et al., 2011).

Interestingly, during the LGM and HS2, the negative $\varepsilon_{\mathrm{Nd}}$ excursions in the EUC are not accompanied by high diatom vs. coccolithophore productivity or large opal fluxes in the Southern Ocean (Fig. 6b and f). Thus, the SOIW exported during the LGM and HS2 had a different chemical composition than the SOIW exported during HS1 and the YD. This might be explained by a latitudinal shift in the SAMW-AAIW formation centers towards lower latitudes as a result of northward repositioning of the westerlies during the HS2 and the LGM (Toggweiler et al., 2006; Pena et al., 2008a; Anderson et al., 2009; Barker et al., 2009; Toggweiler, 2009). Another possibility is shallower convection of intermediate waters, due to reduced salt contributions from the North Atlantic, resulting in less dense SOIW and increased AABW formation (Fig. 6g) and an upward displacement of the SOIWCDW boundary (Pahnke and Zahn, 2005). Moreover, widespread sea ice coverage around Antarctica would favor stratification, and in combination with northward shifted westerlies, would reduce significantly the upwelling of aged, nutrient-rich CDW to the surface ocean (Anderson et al., 2009; Barker et al., 2009; Skinner et al., 2010).

Benthic foraminifera $\delta^{13} \mathrm{C}$ records from intermediate water depths in the Chatham Rise, SW Pacific (Fig. 6d), also show low glacial $\delta^{13} \mathrm{C}$ values (between $\sim 18$ and $30 \mathrm{ka}$ ), consistent with the presence of upper CDW at this depth and indicating that AAIW formation was either shallower or further to the north (Pahnke and Zahn, 2005). At $\sim 17 \mathrm{ka}$ (HS1) and $\sim 12 \mathrm{ka}$ (YD), rapid departures from these glacial low $\delta^{13} \mathrm{C}$ values towards more positive $\delta^{13} \mathrm{C}$ values indicate production of more ventilated AAIW at this SW Pacific site (Fig. 6d). Only during the B-A/Antarctic Cold Reversal (ACR) do benthic $\delta^{13} \mathrm{C}$ values decrease again, indicating a rapid change in AAIW formation due to widespread Southern Hemisphere cooling. The comparison between intermediate water $\delta^{13} \mathrm{C}$ in the SW Pacific, and EUC $\delta^{13} \mathrm{C}$ in the EEP, reveals opposite patterns from $\sim 30 \mathrm{ka}$ until the beginning of the Holocene (Fig. 6d). Glacial $\delta^{13} \mathrm{C}$ values at these two sites show a constant offset, with more positive $\delta^{13} \mathrm{C}$ values in the better ventilated EUC, and more negative $\delta^{13} \mathrm{C}$ values in the intermediate depth SW Pacific. During HS1, $\delta^{13} \mathrm{C}$ values in the EUC show a negative excursion, synchronized with a rapid increase in SW Pacific $\delta^{13} \mathrm{C}$, ending up with identical absolute $\delta^{13} \mathrm{C}$ values at both sites. This pattern is repeated during the YD and reversed during the B-A/ACR, with both $\delta^{13} \mathrm{C}$ records shifting back rapidly towards their glacial $\delta^{13} \mathrm{C}$ levels.

Previous studies have attributed the presence of these negative $\delta^{13} \mathrm{C}$ excursions of thermocline dwelling foraminifera in tropical Pacific deglaciation records to be a result of increased export of SOIW towards the tropical regions (Spero and Lea, 2002; Basak et al., 2010; Bostock et al., 2004; Pena et al., 2008a). Resumption of Southern Ocean upwelling during the onset of deglaciation (Anderson et al., 2009) most likely brought old (low $\delta^{13} \mathrm{C}$ and radiocarbon depleted) CDW to the surface south of the Polar Front (Marchitto et al., 2007, Basak et al., 2010, Fig. 1). Wind stress curl from southward shifted westerlies (Toggweiler, 2009) reinforced the ACC, which in turn enhanced the northward Ekman pumping of the upwelled waters, now partially ventilated through exchange with the atmosphere, to the SAMW-AAIW formation zones. Loss of buoyancy through winter cooling causes partially ventilated surface waters that still carry a low $\delta^{13} \mathrm{C}$ signal to sink. This presumably fast (Spero and Lea, 2002) meridional advection of SOIW takes place without any further exchange with the atmosphere, therefore this low $\delta^{13} \mathrm{C}$ signal behaves quasi-conservatively, reaching the tropical thermocline and marking the EUC with low $\delta^{13} \mathrm{C}$ (Fig. 6d).

In this study, we have confirmed for the first time, using $\mathrm{Nd}$ isotopes on thermocline dwelling foraminifera, that the excursions to lighter $\delta^{13} \mathrm{C}$ in the tropical Pacific thermocline are linked to the advection of SOIW. The combination of $\varepsilon_{\mathrm{Nd}}$ and $\delta^{13} \mathrm{C}$ records also explains the maximum in diatom/coccolithophore ratios found during HS1 and the YD (Fig. 6b). On the other hand, during HS2 and the LGM, the EEP shows low $\varepsilon_{\mathrm{Nd}}$, indicating a substantial SOIW (Fig. 6a and c), while at the same time there is a large difference in $\delta^{13} \mathrm{C}$ values between SW Pacific intermediate waters and the EEP thermocline, and relatively low diatom/ coccolithophore ratios in the EEP (Fig. $6 b$ and d). These relationships can be explained by the arrival of well-ventilated SOIW, which is likely a result of shallower convection of intermediate waters due to reduced salt contributions from the North Atlantic, resulting in less dense SOIW and increased AABW formation (Keeling and Stephens, 2001). Enhanced formation of AABW during HS2 and the LGM is also consistent with the $\varepsilon_{\mathrm{Nd}}$ in deep sea sediments from the South Atlantic (Fig. 6g).

\subsection{Glacial $\mathrm{CO}_{2}$-rich deep water in the Southern Ocean or transient feature?}

Recent studies have found evidence for the existence of a large inventory of 'aged', $\mathrm{CO}_{2}$-rich deep waters around the Southern Ocean during the last glacial period that was sequestered from exchange with the atmosphere (Skinner et al., 2010; Burke and Robinson, 2011). Based on benthic radiocarbon in sediments from the South Atlantic and paired $\mathrm{U}-\mathrm{Th} /{ }^{14} \mathrm{C}$ ages on corals from the Drake Passage, it is estimated that this old deep water mass had a reservoir age of $\sim 3000$ years during the LGM (Fig. 6f). The presence of this old, $\mathrm{CO}_{2}$-rich water mass is consistent with the consensus that glacial-interglacial atmospheric $\mathrm{CO}_{2}$ changes are largely controlled by processes in the Southern Ocean (e.g. Marshall and Speer, 2012). The deglaciation was also accompanied by drastic changes in atmospheric $\mathrm{CO}_{2}$ as well as in atmospheric $\delta^{13} \mathrm{CO}_{2}$ (Fig. $6 \mathrm{~g}$ and $\mathrm{h}$ ). Proxy records indicate that increased upwelling in the Southern Ocean (e.g. younger ventilation ages and increased opal fluxes, Fig. 6f) coincided with the deglacial warming in Antarctica (Fig. 6i) as well as with the rise in atmospheric $\mathrm{CO}_{2}$ (Fig. 6h) and decreased values of atmospheric $\delta^{13} \mathrm{CO}_{2}$ (Fig. 6g). With the upwelling of ${ }^{14} \mathrm{C}$-depleted deep waters to the surface, the same mechanisms that transported $\delta^{13} \mathrm{C}$ depleted waters towards the tropical regions would have also transported ${ }^{14} \mathrm{C}$ depleted intermediate waters, as long as surface waters did not reach equilibrium with the atmosphere. Tropical Pacific studies have shown that ${ }^{14} \mathrm{C}$ ages of benthic foraminifera in cores from intermediate depths off the west coast of Baja California (Fig. 6e) and east of the Galapagos Islands (Stott et al., 2009) indicate injection of ${ }^{14} \mathrm{C}$-depleted intermediate waters during the deglaciation. These injections of 'older' SOIW occurred in two pulses that coincide with intervals of rising atmospheric $\mathrm{CO}_{2}$, and have been interpreted as ${ }^{14} \mathrm{C}$-depleted AAIW that advected towards the tropics as a consequence of increased overturning in the Southern Ocean (Marchitto et al., 2007). However, there is also contradictory evidence against 'older' intermediate waters being transported towards tropical regions. 
Intermediate depth benthic foraminifera ${ }^{14} \mathrm{C}$-ages off the Chile margin (Fig. 6e), and paired $\mathrm{U}-\mathrm{Th} /{ }^{14} \mathrm{C}$ data from deep-sea corals in the Drake Passage (Burke and Robinson, 2011), do not show the characteristic ${ }^{14} \mathrm{C}$-depletion anomaly that would be expected if 'older' intermediate waters were present in the region during the deglaciation.

Additional evidence for the transfer of ${ }^{14} \mathrm{C}$-depleted intermediate waters into the tropics comes from estimating the $\delta^{13} \mathrm{C}$ gradient between the EEP thermocline and the benthic SW Pacific records (SWP-EEP $\Delta{ }^{13} \mathrm{C}$, Fig. 6e). This $\Delta^{13} \mathrm{C}$ gradient represents the coupling between the SW Pacific intermediate waters and EEP thermocline waters, with high values indicating weak coupling and low values indicating a strong similarity in the water chemistries at both sites. The SWP-EEP $\Delta^{13} \mathrm{C}$ record closely matches the benthic foraminifera ${ }^{14} \mathrm{C}$-depletions off Baja California (Fig. 6e), lending further support to a southern origin of ${ }^{14} \mathrm{C}$-depleted intermediate water masses.

Although further work is necessary to explain the absence of ${ }^{14} \mathrm{C}$-depletions in intermediate waters off Chile (De Pol-Holz et al., 2010) and in the Drake Passage (Burke and Robinson, 2011), we hypothesize that changes in the intermediate water convection depth, and/or a meridional-zonal displacement in the formation centers (like the Chilean margin in the modern ocean) could result in the absence of ${ }^{14} \mathrm{C}$-depleted intermediate waters in that region. In the Drake Passage, strong vertical mixing associated with the acceleration of the ACC can result in more efficient vertical homogenization and enhanced exchange of ${ }^{14} \mathrm{C}$ with the atmosphere. While aspects of the ${ }^{14} \mathrm{C}$ data are not clearly consistent with the intermediate water route as a mechanism for the transfer of rapid climatic signal, our results at ODP Site $1240\left(\varepsilon_{\mathrm{Nd}}, \delta^{13} \mathrm{C}\right.$ and organic biomarkers) provide strong evidence that the meridional transport of SOIW or "oceanic tunneling" was an important component in the transfer of climatic signals from the Southern Ocean towards the tropical regions during the last 30 kyr.

\section{Conclusions}

$\mathrm{Nd}$ isotopes in cleaned thermocline dwelling planktonic foraminifera ( $N$. dutertrei) at ODP Site 1240 in the EEP are a robust proxy for the variable transport of SOIW to the tropical Pacific thermocline over the last $30 \mathrm{kyr}$, and can be used to reconstruct past rapid changes in near surface ocean circulation. At Site 1240, the core-top $\varepsilon_{\mathrm{Nd}}(-1.66)$ corresponds to seawater values at $\sim 150$ m depth $(-1.60)$ in the EUC. Additionally, REE of cleaned foraminifera display seawater-like patterns, with LREE depletion and pronounced negative $\mathrm{Ce}$ anomalies, whereas uncleaned foraminifera show shale-like patterns. Laser ablation and solution ICP-MS data indicate a $K_{d} \sim 200$ for $\mathrm{Nd}$, and concentrations of $\sim 0.25 \mathrm{ppm}$ for $N$. dutertrei. These findings confirm that the $\varepsilon_{\mathrm{Nd}}$ in cleaned $N$. dutertrei samples at Site 1240 represent the EUC $\varepsilon_{\mathrm{Nd}}$ at the time of calcification.

EUC $\varepsilon_{\mathrm{Nd}}, \quad \delta^{13} \mathrm{C}$ and organic biomarkers demonstrate that meridional transport of SOIW, or "oceanic tunneling", was an important component in the transfer of climatic signals from the Southern Ocean towards the tropical regions over the last $30 \mathrm{kyr}$. The Site 1240 EUC $\varepsilon_{\mathrm{Nd}}$ record shows increased meridional export of SOIW during climatically cold periods (PB-YD, HS1, LGM, HS2) and reduced export, similar to present day levels, during warm periods (Holocene, B-A). Mixing models strongly indicate that changes in the $\varepsilon_{\mathrm{Nd}}$ at Site 1240 cannot be explained by changes in the $\varepsilon_{\mathrm{Nd}}$ and [Nd] of the Southern Ocean end-member, but rather reflect changes in amount of SOIW reaching the EEP. This is consistent with other intermediate water $\varepsilon_{\mathrm{Nd}}$ records in the western tropical Atlantic indicating enhanced presence of AAIW during the same time periods. Increased northward export of SOIW could be a response to reduced NADW convection during cold intervals, although increased production and advection of SOIW as a result of resumption of Southern Ocean upwelling cannot be ruled out.

Multiple proxy records confirm changes in the chemical composition of SOIW during the deglaciation as a result of the arrival of aged CDW to the surface ocean. These changes are also recorded in the chemistry of the EUC (low $\delta^{13} \mathrm{C}$, increased diatom vs. coccolithopore productivity), thus confirming the rapid transfer of climatic signals from the Southern Ocean to the tropical Pacific by means of SOIW advection. Altogether, the data presented here suggest a strong coupling between global climatic events and changes in the export of SOIW, thus attesting to its sensitivity as a gauge of rapid shifts in the thermohaline circulation, and to its importance as a mechanism for the transfer of climatic signals from high to low latitudes.

\section{Acknowledgements}

We thank J.R Toggweiler and an anonymous reviewer for their valuable comments that led to marked improvement of this paper. L.D.P., S.L.G. and S.R.H. acknowledge support from US National Science Foundation (NSF) Grant OCE-10-31198, and the LDEO Climate Center. E.C., C.P., and I.C. acknowledge funding from the Spanish Ministerio de Ciencia e Innovación through Grants CTM2006-01957/MAR and CTM2009-08849/MAR, from Generalitat de Catalunya (Catalan Government) through Grant 2009SGR142 and a Ramón y Cajal Contract (to E.C.). I.C. also thanks the Spanish GRACCIE CONSOLIDER (CSD2007-00067). S.L.G. acknowledges support from the Storke Endowment of the Columbia University Department of Earth and Environmental Sciences. L.D.P. was partly supported by a LDEO Postdoctoral Fellowship. This research used samples provided by the Ocean Drilling Program (ODP), which is sponsored by the US NSF and participating countries under management of Joint Oceanographic Institutions (JOI). This is LDEO Contribution number 7673.

\section{Appendix A. Supporting information}

Supplementary data associated with this article can be found in the online version at http://dx.doi.org/10.1016/j.epsl.2013.02.028.

\section{References}

Abouchami, W., Goldstein, S.L., Gazer, S.J.G., Eisenhauer, A., Mangini, A., 1997 Secular changes of lead and neodymium in central Pacific seawater recorded by a Fe-Mn crust. Geochim. Cosmochim. Acta 61, 3957-3974.

Adkins, J.F., Boyle, E.A., Keigwin, L., Cortijo, E., 1997. Variability of the North Atlantic thermohaline circulation during the last interglacial period. Nature 390, 154-156.

Ahn, J., Wahlen, M., Deck, B.L., Brook, E.J., Mayewski, P.A., Taylor, K.C., White J.W.C., 2004. A record of atmospheric $\mathrm{CO}_{2}$ during the last 40,000 years from the Siple Dome, Antarctica ice core. J. Geophys. Res. 109, http://dx.doi.org/ 10.1029/2003JD004415.

Anderson, R.F., Ali, S., Bradtmiller, L.I., Nielsen, S.H.H., Fleisher, M.Q., Anderson, B.E., Burckle, L.H., 2009. Wind-driven upwelling in the Southern Ocean and the deglacial rise in atmospheric $\mathrm{CO}_{2}$. Science 323, 1443-1448.

Barker, S., Greaves, M., Elderfield, H., 2003. A study of cleaning procedures used for foraminiferal Mg/Ca paleothermometry. Geochem. Geophys. Geosyst. 4, http://dx. doi.org/10.1029/2003GC000559.

Barker, S., Diz, P., Vautravers, M.J., Pike, J., Knorr, G., Hall, I.R., Broecker, W.S., 2009 Interhemispheric Atlantic seesaw response during the last deglaciation. Nature 457, 1097-1102.

Basak, C., Martin, E.E., Horikawa, K., Marchitto, T.M., 2010. Southern Ocean source of ${ }^{14} \mathrm{C}$-depleted carbon in the North Pacific Ocean during the last deglaciation. Nat. Geosci. 3, 770-773.

Bayon, G., German, C.R., Burton, K.W., Nesbitt, R.W., Rogers, N., 2004. Sedimentary $\mathrm{Fe}-\mathrm{Mn}$ oxyhydroxides as paleoceanographic archives and the role of aeolian flux in regulating oceanic dissolved REE. Earth Planet. Sci. Lett. 224, 477-492. 
Biastoch, A., Böning, C.W., Schwarzkopf, F.U., Lutjeharms, J.R.E., 2009. Increase in Agulhas leakage due to poleward shift of Southern Hemisphere westerlies. Nature 462, 495-498.

Bindoff, N.L., McDougall, T.J., 2000. Decadal changes along an Indian Ocean section at $32^{\circ} \mathrm{S}$ and their interpretation. J. Phys. Oceanogr. 30, 1207-1222.

von Blanckenburg, F., 1999. Tracing past ocean circulation? Science 286, 1862-1863.

Bostock, H.C., Opdyke, N.D., Gagan, M.K., Fifield, L.K., 2004. Carbon isotope evidence for changes in Antarctic Intermediate Water circulation and ocean ventilation in the southwest Pacific during the last deglaciation. Paleoceanography 19, PA4013, http://dx.doi.org/10.1029/2004PA001047.

Bostock, H.C., Opdyke, B.N., Williams, M.J.M., 2010. Characterising the intermediate depth waters of the Pacific Ocean using $\delta^{13} \mathrm{C}$ and other geochemical tracers. Deep-Sea Res. I Oceanogr. Res. Pap. 57, 847-859.

Boyle, E.A., 1976. On the marine geochemistry of cadmium. Nature 263, 42-44.

Boyle, E.A., 1981. Cadmium, Zinc, Copper, and Barium in Foraminifera Tests. Earth Planet. Sci. Lett. 53, 11-35.

Boyle, E.A., 1983. Manganese carbonate overgrowths on foraminifera tests Geochim. Cosmochim. Acta 47, 1815-1819.

Boyle, E.A., 1986. Paired carbon isotope and cadmium data from benthic foraminifera: implications for changes in oceanic phosphorus, oceanic circulation and atmospheric carbon dioxide. Geochim. Cosmochim. Acta 50, 265-276.

Boyle, E.A., Keigwin, L., 1987. North Atlantic thermohaline circulation during the past 20,000 years linked to high-latitude surface temperature. Nature 330, $35-40$.

Boyle, E.A., Keigwin, L.D., 1982. Deep circulation of the North Atlantic over the last 200,000 years: geochemical evidence. Science 218, 784-787.

Broecker, W.S., 1998. Paleocean circulation during the last deglaciation: a bipolar seesaw? Paleoceanography 13, 119-121.

Burke, A., Robinson, L.F., 2011. The Southern Ocean's role in carbon exchange during the last deglaciation. Science 335, 557-561.

Burton, K.W., Vance, D., 2000. Glacial-interglacial variations in the neodymium isotope composition of seawater in the Bay of Bengal recorded by planktonic foraminifera. Earth Planet. Sci. Lett. 176, 425-441.

Calvo, E., Pelejero, C., Logan, G.A., De Deckker, P., 2004. Dust-induced changes in phytoplankton composition in the Tasman Sea during the last four glacial cycles. Paleoceanography 19, PA2020, http://dx.doi.org/10.1029/2003PA000992.

Calvo, E., Pelejero, C., Pena, L.D., Cacho, I., Logan, G.A., 2011. Eastern Equatorial Pacific productivity and related- $\mathrm{CO}_{2}$ changes since the last glacial period. Proc. Natl. Acad. Sci. 108, 5537-5541.

Carter, L., Neil, H.L., Northcote, L., 2002. Late Quaternary ice-rafting events in the SW Pacific Ocean, off eastern New Zealand. Mar. Geol. 191, 19-35.

Carter, P., Vance, D., Hillenbrand, C.D., Smith, J., Shoosmith, D., 2012. The neodymium isotopic composition of waters masses in the eastern Pacific sector of the Southern Ocean. Geochim. Cosmochim. Acta 79, 41-59.

Curry, W.B., Oppo, D.W., 2005. Glacial water mass geometry and the distribution of $\delta^{13} \mathrm{C}$ of $\Sigma \mathrm{CO}_{2}$ in the western Atlantic Ocean. Paleoceanography 20, PA1017, http://dx.doi.org/10.1029/2004PA001021.

De Pol-Holz, R., Keigwin, L., Southon, J., Hebbeln, D., Mohtadi, M., 2010. No signature of abyssal carbon in intermediate waters off Chile during deglaciation. Nat. Geosci. 3, 192-195.

Elderfield, H., Hawkesworth, C.J., Greaves, M., 1981. Rare earth element geochemistry of oceanic ferromanganese nodules and associated sediments. Geochim. Cosmochim. Acta 45, 513-528.

Elmore, A.C., Piotrowski, A.M., Wright, J.D., Scrivner, A.E., 2011. Testing the extraction of past seawater Nd isotopic composition from North Atlantic deep sea sediments and foraminifera. Geochem. Geophys Geosyst. 12, http://dx.doi. org/10.1029/2011GC003741.

Fairbanks, R.G., Sverdlove, M.S., Free, R., Wiebe, P.H., Bé, A.W.H., 1982. Vertical distribution and isotopic fractionation of living planktonic foraminifera from the Panama Basin. Nature 298, 841-844.

Foster, G.L., Vance, D., Prytulak, J., 2007. No change in the neodymium isotope composition of deep water exported from the North Atlantic on glacialinterglacial time scales. Geology 35, 37-40.

Ganopolski, A., Rahmstorf, S., 2001. Rapid changes of glacial climate simulated in a coupled climate model. Nature 409, 153-158.

German, C.R., Masuzawa, T., Greaves, M.J., Elderfield, H., Edmond, J.M., 1995 Dissolved rare earth elements in the Southern Ocean: cerium oxidation and the influence of hydrography. Geochim. Cosmochim. Acta 59, 1551-1558.

Goldstein, S.L., Hemming, S.R., 2003. Long-lived isotopic tracers in oceanography, paleoceanography, and ice-sheet dynamics. In: Treatise on Geochemistry. Elsevier, New York, pp. 453-498.

Goldstein, S.L., O’Nions, R.K., 1981. Nd and Sr isotopic relationships in pelagic clays and ferromanganese deposits. Nature 292, 324-327.

Goodman, P.J., Hazeleger, W., de Vries, P., Cane, M., 2005. Pathways into the Pacific Equatorial Undercurrent: a trajectory analysis. J. Phys. Oceanogr. 35, 2134-2151.

Gruber, N., Gloor, M., Fletcher, S.E.M., Doney, S.C., Dutkiewicz, S., Follows, M.J. Gerber, M., Jacobson, A.R., Joos, F., Lindsay, K., Menemenlis, D., Mouchet, A Müller, S.A., Sarmiento, J.L., Takahashi, T., 2009. Oceanic sources, sinks, an transport of atmospheric $\mathrm{CO}_{2}$. Global Biogeochem. Cycles 23, GB1005, http://d X.doi.org/10.1029/2008GB003349.

Gutjahr, M., Lippold, J., 2011. Early arrival of southern source water in the deep North Atlantic prior to Heinrich event 2. Paleoceanography 26, http://dx.doi.or g/10.1029/2011PA002114.

Haley, B.A., Klinkhammer, G.P., 2002. Development of a flow-through system for cleaning and dissolving foraminiferal tests. Chem. Geol. 185, 51-69.
Haley, B.A., Klinkhammer, G.P., Mix, A.C., 2005. Revisiting the rare earth elements in foraminiferal tests. Earth Planet. Sci. Lett. 239, 79-97.

Horikawa, K., Martin, E.E., Asahara, Y., Sagawa, T., 2011. Limits on conservative behavior of $\mathrm{Nd}$ isotopes in seawater assessed from analysis of fish teeth from Pacific core tops. Earth Planet. Sci. Lett. 310, 119-130.

Ito, T., Woloszyn, M., Mazloff, M., 2010. Anthropogenic carbon dioxide transport in the Southern Ocean driven by Ekman flow. Nature 463, 80-83.

Jacobsen, S.B., Wasserburg, G.J., 1980. Sm-Nd isotopic evolution of chondrites. Earth Planet. Sci. Lett. 50, 139-155.

Jeandel, C., 1993. Concentration and isotopic composition of Nd in the Southern Atlantic Ocean. Earth Planet. Sci. Lett 117, 581-591.

Jeandel, C., Bishop, J.K., Zindler, A., 1995. Exchange of neodymium and its isotopes between seawater and small and large particles in the Sargasso Sea. Geochim. Cosmochim. Acta 59, 535-547.

Joint SOLAS-IMBER Ocean Carbon Research (Implementation Plan no. 1), 2007. Surface Ocean Lower Atmosphere Study (SOLAS) Integrated Marine Biogeochemistry and Ecosystem Research (IMBER).

Jones, K.M., Khatiwala, S.P., Goldstein, S.L., Hemming, S.R., van de Flierdt, T., 2008. Modeling the distribution of $\mathrm{Nd}$ isotopes in the oceans using an ocean general circulation model. Earth Planet. Sci. Lett. 272, 610-619.

Jouzel, J., Lorius, C., Petit, J.R., Genthon, C., Barkov, N.I., Kotlyakov, V.M., Petrov, V.M., 1987. Vostok ice core: a continuous isotope temperature record over the last climatic cycle (160,000 years). Nature $329,403-408$.

Keeling, R.F., Stephens, B.B., 2001. Antarctic sea ice and the control of Pleistocene climate instability. Paleoceanography $16,112-131$.

Keigwin, L., 1998. Glacial-age hydrography of the far northwest Pacific Ocean. Paleoceanography $13,323-339$.

Kessler, W.S., 2006. The circulation of the eastern Tropical Pacific: a review. Prog. Oceanogr. 69, 181-217.

Klevenz, V., Vance, D., Schmidt, D.N., Mezger, K., 2008. Neodymium isotopes in benthic foraminifera: core-top systematics and a down-core record from the Neogene south Atlantic. Earth Planet. Sci. Lett. 265, 571-587.

Kocsis, L., Vennemann, T.W., Fontignie, D., Baumgartner, C., Montanari, A., Jelen, B., 2008. Oceanographic and climatic evolution of the Miocene Mediterranean deduced from $\mathrm{Nd}, \mathrm{Sr}, \mathrm{C}$, and $\mathrm{O}$ isotope compositions of marine fossils and sediments. Paleoceanography 23, PA4211, http://dx.doi.org/10.1029/ 2007PA001540.

Lacan, F., Jeandel, C., 2001. Tracing Papua New Guinea imprint on the central Equatorial Pacific Ocean using neodymium isotopic compositions and Rare Earth Element patterns. Earth Planet. Sci. Lett 186, 497-512.

Lacan, F., Jeandel, C., 2005. Acquisition of the neodymium isotopic composition of the North Atlantic Deep Water. Geochem. Geophys. Geosyst. 6, Q12008, http:// dx.doi.org/10.1029/2005GC000956.

Lippold, J., Luo, Y., Francois, R., Allen, S.E., Gherardi, J., Pichat, S., Hickey, B., Schulz, H., 2012. Strength and geometry of the glacial Atlantic Meridional Overturning Circulation. Nat. Geosci. 5, 813-816.

Lukas, R., 1986. The termination of the Equatorial Undercurrent in the Eastern Pacific. Prog. Oceanogr. 16, 63-90.

Makou, M.C., Oppo, D.W., Curry, W.B., 2010. South Atlantic intermediate water mass geometry for the last glacial maximum from foraminiferal $\mathrm{Cd} / \mathrm{Ca}$ Paleoceanography 25, PA4101, http://dx.doi.org/10.1029/2010PA001962.

Marchitto, T.M., Lehman, S.J., Ortiz, J.D., Flückiger, J., van Geen, A., 2007. Marine radiocarbon evidence for the mechanism of deglacial atmospheric $\mathrm{CO}_{2}$ rise. Science 316, 1456-1459.

Marshall, J., Speer, K., 2012. Closure of the meridional overturning circulation through Southern Ocean upwelling. Nat. Geosci. 5, 171-180.

McManus, J., Francois, R., Gherardi, J.-M., Keigwin, L., Brown-Leger, S., 2004 Collapse and rapid resumption of Atlantic meridional circulation linked to deglacial climate changes. Nature 428, 834-837.

Monnin, E., Indermühle, A., Dällenbach, A., Flückiger, J., Stauffer, B., Stocker, T.F., Raynaud, D., Barnola, J.M., 2001. Atmospheric $\mathrm{CO}_{2}$ concentrations over the last glacial termination. Science 291, 112-114.

Ohkushi, K., Itaki, T., Nemoto, N., 2003. Last Glacial-Holocene change in intermediatewater ventilation in the Northwestern Pacific. Quat. Sci. Rev. 22, 1477-1484.

Osborne, A.H., Vance, D., Rohling, E.J., Barton, N., Rogerson, M., Fello, N., 2008. A humid corridor across the Sahara for the migration of early modern humans out of Africa 120,000 years ago. Proc. Natl. Acad. Sci. 105, 16444-16447.

O'Nions, R.K., Carter, S.R., Cohen, R.S., Evensen, N.M., Hamilton, P.J., 1978. Pb, Nd, and $\mathrm{Sr}$ isotopes in oceanic ferromanganese deposits and ocean floor basalts. Nature 273, 435-438.

Pahnke, K., Zahn, R., 2005. Southern hemisphere water mass conversion linked with North Atlantic climate variability. Science 307, 1741-1746.

Pahnke, K., Goldstein, S.L., Hemming, S.R., 2008. Abrupt changes in Antarctic Intermediate Water circulation over the past 25,000 years. Nat. Geosci. 1 , 870-874.

Palmer, M.R., 1985. Rare earth elements in foraminifera tests. Earth Planet. Sci. Lett. 73, 285-298.

Palmer, M.R., Elderfield, H., 1985, Variations in the Nd isotopic composition of foraminifera from Atlantic Ocean sediments. Earth Planet. Sci. Lett. 73, 299-305.

Palmer, M.R., Elderfield, H., 1986. Rare earth elements and neodymium isotopes in ferromanganese oxide coatings of Cenozoic foraminifera form the Atlantic Ocean. Geochim. Cosmochim. Acta 50, 409-417.

Pena, L.D., Cacho, I., 2009. High- to low-latitude teleconnections during glacial terminations associated with ENSO-like variability. PAGES News $17,5-7$. 
Pena, L.D., Calvo, E., Cacho, I., Eggins, S., Pelejero, C., 2005. Identification and removal of $\mathrm{Mn}-\mathrm{Mg}$-rich contaminant phases on foraminiferal tests: implications for $\mathrm{Mg} / \mathrm{Ca}$ past temperature reconstructions. Geochem. Geophys. Geosyst. 6, http://dx.doi.org/10.1029/2005GC000930.

Pena, L.D., Cacho, I., Ferretti, P., Hall, M.A., 2008a. El Niño-Southern Oscillationlike variability during glacial terminations and interlatitudinal teleconnections. Paleoceanography 23, PA3101, http://dx.doi.org/10.1029/ 2008 PA001620.

Pena, L.D., Cacho, I., Calvo, E., Pelejero, C., Eggins, S., Sadekov, A., 2008b. Characterization of contaminant phases in foraminifera carbonates by electron microprobe mapping. Geochem. Geophys. Geosyst. 9, Q07012, http://dx.doi.or g/10.1029/2008GC002018.

Pichevin, L.E., Reynolds, B.C., Ganeshram, R.S., Cacho, I., Pena, L., Keefe, K., Ellam, R.M., 2009. Enhanced carbon pump inferred from relaxation of nutrient limitation in the glacial ocean. Nature 459, 1114-1117.

Piepgras, D.J., Jacobsen, S.B., 1988. The isotopic composition of neodymium in the North Pacific. Geochim. Cosmochim. Acta 52, 1373-1381.

Piepgras, D.J., Jacobsen, S.B., 1992. The behavior of rare earth elements in seawater: precise determination of variations in the North Pacific water column. Geochim. Cosmochim. Acta 56, 1851-1862.

Piepgras, D.J., Wasserburg, G.J., 1980. Neodymium isotopic variations in seawater. Earth Planet. Sci. Lett. 50, 128-138.

Piepgras, D.J., Wasserburg, G.J., 1982. Isotopic composition of neodymium in waters from the Drake Passage. Science 217, 207-214.

Piepgras, D.J., Wasserburg, G.J., 1987. Rare earth element transport in the western North Atlantic inferred from Nd isotopic observations. Geochim. Cosmochim. Acta 51, 1257-1271.

Piepgras, D.J., Wasserburg, G.J., Dasch, E.J., 1979. The isotopic composition of Nd in different ocean masses. Earth Planet. Sci. Lett. 45, 223-236.

Piotrowski, A.M., Goldstein, S.L., Hemming, S.R., Fairbanks, R.G., 2004. Intensification and variability of ocean thermohaline circulation through the last deglaciation. Earth Planet. Sci. Lett. 225, 205-220.

Piotrowski, A.M., Goldstein, S.L., Hemming, S.R., Fairbanks, R.G., 2005. Temporal relationships of carbon cycling and ocean circulation at glacial boundaries. Science 307, 1933-1938.

Piotrowski, A.M., Goldstein, S.L., Hemming, S.R., Fairbanks, R.G., Zylberberg, D.R., 2008. Oscillating glacial northern and southern deep water formation from combined neodymium and carbon isotopes. Earth Planet. Sci. Lett. 272, 394-405.

Pomiès, C., Davies, G.R., Conan, M.-H., 2002. Neodymium in modern foraminifera from the Indian Ocean: implications for the use of foraminiferal Nd isotope compositions in paleo-oceanography. Earth Planet. Sci. Lett 203, 1031-1045.

Rempfer, J., Stocker, T.F., Joos, F., Dutay, J.-C., Siddall, M., 2011. Modelling Ndisotopes with a coarse resolution ocean circulation model: sensitivities to model parameters and source/sink distributions. Geochim. Cosmochim. Acta 75, 5927-5950.

Rickli, J., Frank, M., Halliday, A.N., 2009. The hafnium-neodymium isotopic composition of Atlantic seawater. Earth Planet. Sci. Lett. 280, 118-127.

Roberts, N.L., Piotrowski, A.M., McManus, J.F., Keigwin, L.D., 2010. Synchronous Deglacial Overturning and water mass source changes. Science 327, 75-78.

Roberts, N.L., Piotrowski, A.M., Elderfield, H., Eglinton, T.I., Lomas, M.W., 2012. Rare earth element association with foraminifera. Geochim. Cosmochim Acta 94 57-71.

Robinson, L.F., van de Flierdt, T., 2009. Southern Ocean evidence for reduced export of North Atlantic Deep Water during Heinrich event 1. Geology 37, 195-198.

Rodgers, K.B., Lohmann, G.P., Lorenz, S., Schneider, R.R., Henderson, G.M., 2003. A tropical mechanism for Northern Hemisphere deglaciation. Geochem. Geophys. Geosyst. 4, http://dx.doi.org/10.1029/2003GC000508.

Rutberg, R.L., Hemming, S.R., Goldstein, S.L., 2000. Reduced North Atlantic Deep Water flux to the glacial Southern Ocean inferred from neodymium isotope ratios. Nature 405, 935-938.

Saenko, O., Weaver, A., Gregory, J., 2003. On the link between the two modes of the ocean thermohaline circulation and the formation of global-scale water masses. J. Clim. 16, 2797-2801.

Schmitt, J., Schneider, R., Elsig, J., Leuenberger, D., Lourantou, A., Chappellaz, J., Kohler, P., Joos, F., Stocker, T.F., Leuenberger, M., Fischer, H., 2012. Carbon isotope constraints on the deglacial $\mathrm{CO}_{2}$ rise from ice cores. Science 336, 711-714.

Shaw, H.F., Wasserburg, G.J., 1985. Sm-Nd in marine carbonates and phosphates: implications for Nd isotopes in seawater and crustal age. Geochim. Cosmochim. Acta 49, 503-518.

Siddall, M., Khatiwala, S., van de Flierdt, T., Jones, K., Goldstein, S.L., Hemming, S. Anderson, R.F., 2008. Towards explaining the Nd paradox using reversible scavenging in an ocean general circulation model. Earth Planet. Sci. Lett. 274, 448-461.

Skinner, L.C., Fallon, S., Waelbroeck, C., Michel, E., Barker, S., 2010. Ventilation of the deep Southern Ocean and deglacial $\mathrm{CO}_{2}$ rise. Science 328, 1147-1151.

Spero, H.J., Lea, D.W., 2002. The cause of carbon isotope minimum events on glacial terminations. Science 296, 522-525.

Stichel, T., Frank, M., Rickli, J., Haley, B.A., 2012. Hafnium and neodymium isotope composition of seawater in the Atlantic sector of the Southern Ocean. Earth Planet. Sci. Lett. 317-318, 282-294.

Stoll, H.M., Vance, D., Arevalos, A., 2007. Records of the Nd isotope composition of seawater from the Bay of Bengal: implications for the impact of Northern Hemisphere cooling on ITCZ movement. Earth Planet. Sci. Lett 255, 213-228.

Stott, L.D., Southon, J., Timmermann, A., Koutavas, A., 2009. Radiocarbon age anomaly at intermediate water depth in the Pacific Ocean during the las deglaciation. Paleoceanography 24, PA2223, http://dx.doi.org/10.1029/ 2008PA001690.

Tachikawa, K., Jeandel, C., Vangriesheim, A., Dupré, E., 1999. Distribution of rare earth elements and neodymium isotopes in suspended particles of the tropical Atlantic Ocean (EUMELI site). Deep-Sea Res. I 46, 733-755.

Tachikawa, K., Athias, V., Jeandel, C., 2003. Neodymium budget in the modern ocean and paleo-oceanographic implications. J. Geophys. Res. 108, http://dx.do i.org/10.1029/1999JC000285.

Taylor, S.R., McLennan, S.M., 1985. The Continental Crust: Its Composition and Evolution; an Examination of the Geochemical Record Preserved in Sedimentary Rocks. Blackwell, Oxford 312 pp.

Tazoe, H., Obata, H., Gamo, T., 2006. Vertical profiles of cerium and neodymium isotopic compositions and REEs pattern in the Ross Sea. Geochim. Cosmochim. Acta 70, A640.

Timmermann, A., Okumura, Y., An, S.-I., Clement, A.C., Dong, B., Guilyardi, E., Hu, A., Jungclaus, J.H., Renold, M., Stocker, T.F., Stouffer, R.J., Sutton, R., Xie, S.-P., Yin, J., 2007. The influence of a weakening of the Atlantic meridional overturning circulation on ENSO. J. Clim. 20, 4899-4919.

Toggweiler, J.R., 2009. Shifting Westerlies. Science 323, 1434-1435.

Toggweiler, J.R., Dixon, K., Broecker, W.S., 1991. The Peru upwelling and the ventilation of the South Pacific thermocline. J. Geophys. Res. 96, 20467-20497.

Toggweiler, J.R., Russell, J.L., Carson, S.R., 2006. Midlatitude westerlies, atmospheric $\mathrm{CO}_{2}$, and climate change during the ice ages. Paleoceanography 21 PA2005, http://dx.doi.org/10.1029/2005PA001154.

Tsuchiya, M., 1991. Flow path of the Antarctic intermediate water in the western equatorial South Pacific Ocean. Deep-Sea Res. I 38, 273-279.

Tsuchiya, M., Lukas, R., Fine, R.A., Firing, E., Lindstrom, E.J., 1989. Source waters of the Pacific Equatorial Undercurrent. Prog. Oceanogr. 23, 101-147.

Vance, D., Burton, K., 1999. Neodymium isotopes in planktonic foraminifera: a record of the response of continental weathering and ocean circulation rates to climate change. Earth Planet. Sci. Lett. 173, 365-379.

Vance, D., Scrivner, A.E., Beney, P., Staubwasser, M., Henderson, G.M., Slowey, N.C., 2004. The use of foraminifera as a record of the past neodymium isotope composition of seawater. Paleoceanography 19, PA2009, http://dx.doi.org/ $10.1029 / 2003$ PA000957.

van de Flierdt, T., Robinson, L.F., Adkins, J.F., Hemming, S.R., Goldstein, S.L., 2006 Temporal stability of the neodymium isotope signature of the Holocene to glacial North Atlantic. Paleoceanography 21, PA4102, http://dx.doi.org/ 10.1029/2006PA001294.

Wells, M.L., Vallis, G.K., Silver, E.A., 1999. Tectonic processes in Papua New Guinea and past productivity in the eastern equatorial Pacific Ocean. Nature 398 601-604

Werne, J.P., Hollander, D.J., Lyons, T.W., Peterson, L.C., 2000. Climate-induced variations in productivity and planktonic ecosystems structure from the Younger Dryas to Holocene in the Cariaco Basin. Paleoceanography 15, 19-29.

Wong, A.P.S., Bindoff, N.L., Church, J.A., 1999. Large-scale freshening of intermediate waters in the Pacific and Indian oceans. Nature 400, 440-443.

Xie, R.C., Marcantonio, F., Schmidt, M.W., 2012. Deglacial variability of Antarctic Intermediate Water penetration into the North Atlantic from authigenic neodymium isotope ratios. Paleoceanography 27, PA3221, http://dx.doi.org $10.1029 / 2012$ PA002337.

Zahn, R., Schönfeld, J., Kudrass, H.-R., Park, M.-H., Erlenkeuser, H., Grootes, P.M., 1997. Thermohaline instability in the North Atlantic during meltwater events: stable isotope and ice-rafted detritus records from core SO75-26KL, Portuguese margin. Paleoceanography 12, 696-710.

Zhong, S., Mucci, A., 1995. Partitioning of rare earth elements (REEs) between calcite and seawater solutions at $25 \mathrm{C}$ and $1 \mathrm{~atm}$, and high dissolved REE concentrations. Geochim. Cosmochim. Acta 59, 443-453. 